\title{
CEO Education and Corporate Environmental Footprint
}

\author{
Amore, Mario Daniele; Bennedsen, Morten; Larsen, Birthe; Rosenbaum, Philip
}

Document Version

Accepted author manuscript

Published in:

Journal of Environmental Economics and Management

DOI:

10.1016/j.jeem.2019.02.001

Publication date:

2019

\section{License \\ CC BY-NC-ND}

Citation for published version (APA):

Amore, M. D., Bennedsen, M., Larsen, B., \& Rosenbaum, P. (2019). CEO Education and Corporate Environmental Footprint. Journal of Environmental Economics and Management, 94, 254-273. https://doi.org/10.1016/j.jeem.2019.02.001

Link to publication in CBS Research Portal

\section{General rights}

Copyright and moral rights for the publications made accessible in the public portal are retained by the authors and/or other copyright owners and it is a condition of accessing publications that users recognise and abide by the legal requirements associated with these rights.

Take down policy

If you believe that this document breaches copyright please contact us (research.lib@cbs.dk) providing details, and we will remove access to the work immediately and investigate your claim. 


\section{CEO Education and Corporate Environmental Footprint} Mario Daniele Amore, Morten Bennedsen, Birthe Larsen, Philip Rosenbaum

Journal article (Accepted manuscript*)

\section{Please cite this article as:}

Amore, M. D., Bennedsen, M., Larsen, B., \& Rosenbaum, P. (2019). CEO Education and Corporate Environmental Footprint. Journal of Environmental Economics and Management, 94, 254-273. https://doi.org/10.1016/j.jeem.2019.02.001

DOl: 10.1016/j.jeem.2019.02.001

* This version of the article has been accepted for publication and undergone full peer review but has not been through the copyediting, typesetting, pagination and proofreading process, which may lead to differences between this version and the publisher's final version AKA Version of Record.

Uploaded to CBS Research Portal: March २०२०

(C) २019. This manuscript version is made available under the CC-BY-NC-ND 4.0 license http://creativecommons.org/licenses/by-nc-nd/4.0/ 


\section{Accepted Manuscript}

CEO Education and Corporate Environmental Footprint

Mario Daniele Amore, Morten Bennedsen, Birthe Larsen, Philip Rosenbaum

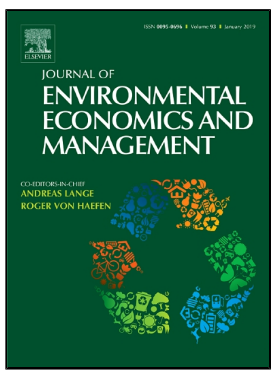

PII:

S0095-0696(17)30851-3

DOI:

10.1016/j.jeem.2019.02.001

Reference:

YJEEM 2215

To appear in:

Journal of Environmental Economics and Management

Received Date:

11 December 2017

Accepted Date:

04 February 2019

Please cite this article as: Mario Daniele Amore, Morten Bennedsen, Birthe Larsen, Philip Rosenbaum, CEO Education and Corporate Environmental Footprint, Journal of Environmental Economics and Management (2019), doi: 10.1016/j.jeem.2019.02.001

This is a PDF file of an unedited manuscript that has been accepted for publication. As a service to our customers we are providing this early version of the manuscript. The manuscript will undergo copyediting, typesetting, and review of the resulting proof before it is published in its final form. Please note that during the production process errors may be discovered which could affect the content, and all legal disclaimers that apply to the journal pertain. 


\section{CEO Education and Corporate Environmental Footprint}

Mario Daniele Amore is at Bocconi University (mario.amore@unibocconi.it). Morten Bennedsen is the Niels Bohr Professor at University of Copenhagen and the André and Rosalie Chaired Professor at INSEAD (morten.bennedsen@,insead.edu). Birthe Larsen and Philip Rosenbaum are at Copenhagen Business School (bl.eco@cbs.dk and pr.eco@,cbs.dk). For useful comments and suggestions, we thank Antonio Fatas, Alfonso Gambardella, Maria Guadalupe, Nicholas Rivers (editor), Giovanni Valentini, two anonymous reviewers, and seminar participants at INSEAD, Stockholm School of Economics, Copenhagen Business School, Bocconi University, as well as conference participants at the Shanghai/Review of Finance Green Finance Conference, Economic Policy Research Network (EPRN) Conference, European Economic Association (EEA/ESEM) Annual Meeting, University of Oxford Conference on Econometric Models of Climate Change, CBS International Conference on Business, Policy and Sustainability, and Copenhagen Education Network Workshop. Funding from Danish Research Council (FSE), Danish National Research Foundation and Economic Policy Research Network is gratefully acknowledged. 


\title{
CEO Education and Corporate Environmental Footprint
}

January 30, 2019

\begin{abstract}
We analyze the effect of CEO education on environmental decision-making. Using a unique sample of Danish firms from 1996 to 2012, we find that CEO education significantly improves firms' energy efficiency. We seek to derive causality using health shocks: the hospitalization of highly educated CEOs induces a drop in energy efficiency, whereas the hospitalization of less educated CEOs does not have any significant effect. Exploring the mechanisms at play, we show that our results are largely driven by advanced education in business degrees. Moreover, we show that CEO education is associated with greater environmental awareness: highly educated CEOs exhibit greater concerns for climate change, as measured by a survey of social preferences, and drive more environmentally efficient cars. Taken together, our findings suggest that education shapes managerial styles giving rise to greater sustainability in corporate actions.
\end{abstract}

Keywords: CEOs; Education; Climate Change; Energy Efficiency

JEL Codes: G34; I20; J24; Q50 


\section{Introduction}

This paper analyzes the effect of CEO education on environmental decision-making. Several works in the literature have been devoted to quantifying the impact of human capital on economic outcomes such as labor market returns (e.g. Card 2001), financial decision-making (e.g. Cole et al. 2014; Black et al. 2018) and lifetime wealth (e.g. Oreopoulos 2007). Moreover, the literature has suggested that education is not only beneficial for individuals but may breed benefits to the entire society. ${ }^{1}$ This argument can be traced back to at least Friedman (1955: pg. 2), who noted that "A stable and democratic society is impossible without a minimum degree of literacy and knowledge on the part of most citizens and without widespread acceptance of some common set of values. Education can contribute to both. In consequence, the gain from education of a child accrues not only to the child or to his parents but also to other members of the society". More recently, Putnam (1995: pg. 672) argued that "education is by far the strongest correlate that I have discovered of civic engagement in all its forms." Empirical studies provide support for this view by showing that education increases voter participation, support for free speech, public awareness and political involvement (Dee 2004; Milligan et al. 2004). ${ }^{2}$ Along this line, Meyer (2015) shows that educated individuals are more concerned about social welfare and environmental issues, while Volland (2017) documents that social trust is negatively correlated with energy demand at the household level. ${ }^{3}$

We contribute to this literature by studying the impact of education on a CEO's environmental stance. We find that better educated CEOs reduce their environmental footprint by spurring corporate energy efficiency and making greener private decisions. CEOs provide a

\footnotetext{
${ }^{1}$ See also Krueger and Lindahl (2001) for a discussion.

${ }^{2}$ Huang et al. (2009) provide evidence that education increases social trust and public participation. Brand (2010) shows that these effects are stronger for individuals who are otherwise less likely to obtain higher education.

${ }^{3}$ More generally, there is evidence suggesting that cultural views affect the way in which individuals handle collective action problems (Cherry et al. 2017).
} 
context of utmost importance for our study. First, CEOs have ultimate influence on corporate policies, which may amplify the consequences of their personal environmental commitment (or lack thereof). Second, CEO decisions may significantly affect the environmental sustainability of other firms in the value chain (Dai et al. 2018) via e.g. stakeholder engagement, imitation and knowledge transfer. Despite such relevance, the effect of CEO traits on firms' environmental policies remains, to our knowledge, largely unexplored.

We collect data from the Danish Environmental Protection Agency data covering the energy consumption of 428 Danish manufacturing companies from 1996 to 2012. For each of these companies, we gather register data on CEO education and several other demographic characteristics. Our results indicate that firms led by highly educated CEOs use significantly less energy per output. In economic terms, an additional year of CEO education is associated with $7 \%$ lower electricity and $17 \%$ lower gas (all scaled by employees), as well as a $20 \%$ higher efficiency in a composite index based on the use of energy inputs within a given industry.

While this result holds controlling for several variables related to the industry, firm and CEO level, we acknowledge that the endogenous matching between companies and CEOs poses an empirical challenge to interpret our results causally. We try to overcome this challenge by exploiting CEO hospitalization events. As argued in Bennedsen et al. (2018), this approach helps to tease out the causal effect of CEOs on corporate policies given that hospitalization events exogenously change CEO exposure without altering the CEO-firm match. The hospitalization of highly educated CEOs may lower current energy use through at least two channels. First, environmental projects typically rest on cognitively demanding tasks that require changes in existing routines and novel recombination of existing approaches. When highly educated CEOs are hospitalized, there is a sudden lack of leadership inputs which impairs energy-related projects, 
in particular if other top managers have to cover up for the absent $\mathrm{CEO}$ on the part of the CEO job that is not related to energy projects. Second, hospitalization induces an increase in CEO's personal risk. Hospitalized CEOs may be spending effort and time on personal well-being, and may even start to consider leaving the helm of the company. This process takes focus away from such complex activities as energy-preserving projects. Moreover, hospitalization may reduce a CEO's ability and incentives to monitor the activities of the company, and thus weakens employees' incentive to work hard on energy-saving tasks. Customers and suppliers may also face weaker incentives to invest in complex relationship with firms led by hospitalized CEOs, thus reducing the resources available to energy-related projects. Our results indicate that, as compared to CEOs without college education, the hospitalization of highly educated CEOs has a significant and negative effect on firms' electricity efficiency: for an additional day that highly educated CEOs spend in the hospital, the electricity efficiency of their firms declines by $7 \%$ to $9 \%$ depending on the specification.

There are two interpretations for our findings so far. The first builds on the notion that education spurs managerial efficiency: accordingly, more educated managers may be better able to identify and pursue energy-saving approaches leading to a lower utilization of energy inputs. This evidence is related to Bloom et al. (2010), who find that good managerial practices improve energy efficiency. The second argument builds on the association between education and civic engagement (Dee 2004; Milligan et al. 2004), which suggests that highly educated CEOs may embrace a universalistic managerial style characterized by greater awareness of environmental priorities and better alignment between corporate and societal goals. Both of these arguments propose that more educated CEOs achieve superior environmental performance; however, the first argument implies that the effect arises from managerial skills (and is thus largely specific to 
some fields of study) whereas according to the second the effect stems from the level of cumulated education. Separating out these explanations empirically is difficult. We address this challenge by comparing CEOs' educational attainment across different fields of study. Our results indicate that energy efficiency mainly arises by holding advanced degrees in businessrelated disciplines.

We move to study the individual actions behind our results so far. Recent evidence suggests that CEOs tend to bring their own personal beliefs into corporate decision-making (Cronqvist et al. 2012). Accordingly, we posit that CEO education may be positively associated with personal awareness of climate change. Our results indicate that highly educated CEOs are significantly more concerned about climate change, as proxied by a survey-based measure of environmental concerns covering more than 5,000 CEOs. This result holds controlling for confounding factors such as gender, age and income, while also tackling endogeneity concerns by using parents' education as instrumental variables while controlling for parents' political and religious values (which may have had a direct effect on offspring's preferences toward the environment). Next, we establish the material implications of education on CEOs' personal choices by focusing on car purchase decisions, a topic currently under scrutiny (e.g. Yan and Eskeland 2018) given that cars are an important driver of pollution with significant implications for health conditions (Knittel et al. 2016). Our results suggest that CEO education has a positive and significant effect on the decision to purchase fuel-efficient cars, as measured by: (1) greater kilometer per liter of fuel, and (2) greater likelihood of owning an electric car. These findings too hold controlling for CEO income and other personal characteristics including age, gender and area of residence. 
Our paper offers novel insights to the underexplored relationship between the educational level of top executives and the environmental footprint of the organizations they lead. The seminal study by Bertrand and Schoar (2003) provided early evidence on the presence of managerial styles. ${ }^{4}$ Recent works show that the impact of managerial styles on firm performance is stronger for highly educated CEOs (Bennedsen et al. 2018). Companies led by CEOs with better educational credentials achieve greater financial performance (Falato et al. 2015; King et al. 2016; Miller et al. 2015), while companies led by CEOs with science-related degrees engage in more R\&D spending. By bridging the literature on managerial traits (e.g. Bertrand and Schoar 2003; Malmendier and Tate 2005, 2008) with that on the determinants of firms' environmental efficiency (e.g. Bloom et al. 2010; Popp 2002; Martin et al. 2012), our study provides important contributions to the debate on why some firms pollute more than others (Shapira and Zingales 2017). Corporate environmental actions are shaped by a complex set of firm-level and external determinants including a country's legal framework (Liang and Renneboog 2017), industry competition (Fernandez-Kranz and Santaló 2010), energy price and policies (e.g. Popp 2002; Nesta et al. 2014), organization and management practices (Bloom et al. 2010; Boyd and Curtis 2014; Martin et al. 2012) and corporate governance (Amore and Bennedsen 2016; Ferrell et al. 2016; Kock et al. 2012). This web of determinants induces a substantial heterogeneity in energy efficiency, which may even exceed the heterogeneity found in traditional productivity measures (Lyubich et al. 2018). Our contribution to this debate is to empirically show that the environmentally-conscious management style of educated CEOs has a positive effect on a firm's energy efficiency.

\footnotetext{
4 Building on this notion, many works have explored the origins of managerial styles by focusing on CEOs' individual and family characteristics (e.g. Adams and Ferreira 2009; Cronqvist and Yu 2017; Yim 2013), professional background and experience (e.g. Custodio and Metzger 2013; Dittmar and Duchin 2016).
} 
Our research has relevant implications along three directions. First, from the business perspective, energy consumption can represent a significant production cost, and our study suggests that CEO education is a managerial trait that provides relevant variations of such costs. Second, a growing research documents that socially-responsible actions may have significant implications for shareholder value (e.g. Deng et al. 2013; Kruger 2015; Flammer 2015; Servaes and Tamayo 2013), for instance because investment in corporate social responsibility facilitates the access to debt financing (Amiraslani et al. 2017) or because investors are sin averse due to social norms (Hong and Kacperczyk 2009). We argue that education shapes managerial styles in a way that may be beneficial not just for shareholders, as the previous literature has suggested, but also for the environment. Third, understanding what drives firms to produce more efficiently can help policy-makers design effective environmental policies which take into account not only traditional factors such as production inputs or industry specialization but also the demographic traits and human capital of top executives.

The rest of the paper is organized as follows. Section 2 describes the data and shows the main summary statistics. Section 3 illustrates the relationship between CEO education and corporate energy efficiency and discusses our econometric strategies. Section 4 is concerned with the CEOs personal values and private choices. Section 5 concludes.

\section{Data and summary statistics}

Our data come from various registers managed by Statistics Denmark and other sources, which provide us with comprehensive information at the firm and CEO level. In this section, we illustrate each data source and discuss the match between individual-level information and company data containing environmental and accounting items. 


\subsection{Firm-level data}

We employ data from two separate sources, which are merged to form a longitudinal dataset of Danish firms from 1996 through 2012. ${ }^{5}$ The first source is represented by the annual reports submitted by companies to the Danish Environmental Protection Agency as part of the Green Accounting program, introduced in 1995 and aimed at increasing the public awareness of Danish firms' environmental activities. The quality of these reports is ensured by central supervisory authorities of the Danish Ministry of Environment and Food. Every firm is assigned a supervisor, who goes through the green report and evaluates its completeness, consistency and reliability. Disclosing environmental data has been mandatory for firms in such sectors as manufacturing, infrastructure, transportation, power plants, mining and quarrying, and waste disposal. ${ }^{6}$ Although the green reports have been filed in different formats and to different institutions, it is possible to observe each firm over time. We have therefore accessed all the environmental reports and extracted the environment-related variables from 1996 to 2012.

Our second source is Experian, an annual register containing detailed accounting and management information for all limited-liability and privately-held Danish firms. These companies are obliged to deliver a comprehensive set of financial items to the Danish Ministry of Business and Growth every year. According to the Danish corporate law, firms' financial reports have to be approved by external accountants, a procedure which raises the credibility of the data.

\footnotetext{
5 Our dataset does not include the year 2008 due to a change in how the data were recorded by the Danish Environmental Agency.

${ }^{6}$ The specific sectors are: iron, steel, other metals, plastic coatings, cement, glass, glass fibers, mineral wool, pottery, ceramics, electro graphite, carbon, asbestos, chalk, calcium, tar, minerals, organic and inorganic chemicals, fertilizers, medicine, dyes, food additives, plant protection substances, biocides, polyurethane foam, paper, cellulose, textiles, alcohol, yeast, sugar, industry bakeries, potato flour, slaughterhouses, fish meal, meat meal, leather, diary, sea food, shell fish and proteins. A minor legislative change implemented in 2010 lowered by around 35\% the number of firms obliged to report their Green Accounts.
} 
Unfortunately, firms are not obliged to report all accounting items, and this explains a greater number of missing values in some items such as revenues. The management section of this data source includes the identifier of each CEO, which Danish firms are required to report annually.

\subsection{Education and other CEO-level data}

The Danish educational system is primarily public and no tuition fees are demanded. We categorize the different educational levels in three groups. The first, Non-college degrees, consists of primary and lower-secondary school (9-10 years of schooling mandatory for all Danes), high school (upper secondary school, which is optional and takes 3 years), vocational education (an alternative to high school with a typical duration of 3 years) and short academy professional programs (with a duration of maximum 2 years). The second, Undergraduate degrees, consists of 3 to 3.5 years long post high school professional bachelor and undergraduate programs (academic bachelor's program). The third, Master or $\mathrm{PhDs}$, consists of university graduate programs, where a master degree takes 2 years (on top of the 3 years for the undergraduate), and 3 additional years to get a PhD. Figure A1 provides an illustration of the Danish educational system.

To study how CEO education affects green behavior, we access the Educational Register (UDDA), which contains data on the educational attainment of all graduates from any Danish educational institution. From this register, we gather the years of education, type of degree, year of graduation and institution for each CEO in our sample. We use other registers to collect other demographic variables such as CEOs' age, gender, area of residence, marital status and income.

\subsection{Sample and summary statistics}


Common to the literature (e.g. Bloom et al. 2010; Brunnermeier and Cohen 2003; Jaffe and Palmer 1997), we focus on firms that operate in the manufacturing sector. The key advantage of this choice is that in manufacturing industries energy usage is a significant input of the production process. After cleaning and merging the data, we obtain 428 unique manufacturing firms for a total of 2,491 firm-year observations. ${ }^{7}$

Our main variable of interest is the logarithm of a firm's electricity consumption scaled by the number of employees. Electricity consumption is a reliable measure of a firm's overall energy consumption and it is often easy to monitor. Employees are typically less volatile than profits and thus provide a better scaling factor than, say, operating profits. Nevertheless, we check that our results are robust to scaling electricity consumption by fixed assets or profit measures. Different firms use different energy sources, which can be close substitutes. To account for this issue, we employ alternative energy-related items in the numerator, such as gas and water consumption, or composite indexes that capture energy efficiency more broadly (see Section 3.3 for details).

Summary statistics are presented in Table 1. Panel A shows that the average firm has 168 employees and DKK 342 million (i.e. approximately 53.6 million \$) in total assets, whereas Panel B shows that the average firm uses 4.2 billion $\mathrm{kWh}$ annually. The two panels also show that energy consumption, capital and employees vary considerably, indicating a wide variation across firm sizes. This underpins the importance of scaling energy consumption variables by the firm's number of employees. Panel $\mathrm{C}$ shows the distribution of firms across the manufacturing subindustries.

\footnotetext{
${ }^{7}$ Specifically, we start from a sample of 1,013 firms in the green accounting program. We drop 285 firms with missing information on the key energy variables, 209 firms that do not operate in manufacturing industries, 16 firms without information on the number of employees (our scaling factor for the measure of electricity efficiency), and 75 firms with missing information on the individual characteristics of the CEO. As a result, we obtain 428 unique firms for a total of 2,491 observations.
} 
Insert Table 1 about here

In Table 2, we provide summary statistics for CEO characteristics. As shown, the CEOs in our sample are almost exclusively men, they are on average 53 years old and have undergone 15 years of education. 53\% of the CEOs hold an undergraduate or higher degree. Of these, 49\% hold “Technical advanced degrees", consisting of engineering or natural sciences, 38\% hold degrees in "Business advanced degrees", consisting of degrees in business or economics, and 13\% hold some "Other advanced degree" mostly consisting of degrees in humanities.

Table 3 reports the average firm characteristics by different levels of CEO education. Panel A shows that firm size, measured in total assets, fixed assets and employees, is increasing in CEO education. Panel B presents the average firm characteristics by CEOs' educational level, while Table A1 offers a detailed description of each variable used in the empirical analysis.

Insert Table 2 about here

Insert Table 3 about here

\section{CEO education and corporate energy efficiency}

In this section, we estimate the association between the length of CEO education and electricity usage. Seeking to establish causality, we adopt an empirical identification based on hospitalization shocks. Then, we go beyond the focus on electricity and show the effect of CEO education on 
several dependent variables capturing energy efficiency more broadly. Finally, we explore the effect of specific fields of study.

\subsection{Baseline results}

We begin by estimating the following regression:

$$
y_{i t}=\beta_{1} \text { Education }_{i t}+\mathbf{M}_{i t} \beta_{2}+\mathbf{F}_{i t} \beta_{3}+\delta \text { Industry }_{i}+\gamma \text { Year }_{t}+u_{i t}
$$

where $y_{i t}$ is the logarithm of electricity over employees for the firm $i$ at time $t$. Education is the CEO's educational level, measured in years. $\mathbf{M}_{i t}$ is a vector containing individual characteristics such as age and gender, which may correlate with environmental attitudes and thus confound the education effect. $\mathbf{F}_{i t}$ is a vector containing a firm's financial variables such as capital intensity (computed as the ratio of total assets to employees) and asset growth (measured as the annual growth in total assets), which are commonly employed as controls in the environmental economics literature (e.g. Bloom et al. 2010). ${ }^{8}$ Industry is a set of industry dummies that capture the time-invariant sectoral heterogeneity within the manufacturing sector. ${ }^{9}$ Year is a set of year dummies included to absorb time effects common to all firms. We estimate this regression with pooled OLS and compute robust standard errors clustered at the firm level to account for both heteroscedasticity and serial correlation in the structure of residuals. ${ }^{10}$

In Column (1) of Panel A, Table 4, we regress electricity efficiency on the CEO's educational level and only control for year and industry dummies. As shown, CEO education is

\footnotetext{
${ }^{8}$ In untabulated checks, we further validate our findings using a broader set of controls including e.g. the ratio of intangibles to total assets, and profitability (computed as the ratio of operating profits to total assets).

9 The main approach to account for industry effects is based on a classification including 23 different industries. As we will show, our results hold using finer industry classifications based on 53 or 111 different industries.

${ }^{10}$ Notice that since CEO education does not change over time we do not include firm fixed effects in our baseline analysis. Indeed, in our sample, there are 428 firms and very few of them changes CEO. Firms that change CEO (1) hire from outside the pool of $428 \mathrm{CEOs,}$ which raises concerns of endogenous matching; (2) hire a CEO who is likely to have education similar to that of the outgoing CEO, which does not yield enough variation for our estimation. However, we address concerns of omitted factor bias at the CEO level in Sections 3.2 and 3.3.
} 
negatively and significantly associated with electricity per employee. In economic terms, the coefficient indicates that an additional year of CEO education is associated with a $7 \%$ higher electricity efficiency. Column (2) shows that this effect remains significant when controlling for CEOs' age and gender. In Columns (3)-(4), we further control for a firm's capital intensity, asset growth, and the logarithm of total assets. Looking at the coefficient of these variables, we find that firm growth and firm size are both associated with lower electricity efficiency, either because fast-growing firms sacrifice environmental goals during their expansion process or because higher energy intensity supports the firms in growing. Moreover, we find that capital per worker is positively associated with electricity efficiency. Despite the inclusion of these controls, our main result on $\mathrm{CEO}$ educational level remains significant at the $1 \%$ level.

In Panel B of Table 4, we estimate the regression using a set of education dummies instead of our baseline variable measuring years of schooling. We use three categories: noncollege education (baseline), undergraduate degree, and Master or $\mathrm{PhD}$ degree. As compared to CEOs with non-college degree, holding an undergraduate degree has a positive and significant (at the $10 \%$ level) effect on electricity efficiency. This effect becomes much stronger, both economically and statistically, for CEOs holding a Master of PhD degree: the coefficient indicates a $38 \%$ increase in electricity efficiency relative to firms with CEOs holding a noncollege degree. These findings suggest that the effect of CEO education on a firm's environmental stance is stronger for CEOs with the highest educational attainment, possibly owing to the fact that environmental activities typically rest on cognitively demanding tasks that require changes in existing routines and novel recombination of existing approaches (see Amore and Bennedsen 2016 for related arguments). 
Insert Table 4 about here

\subsection{Evidence from $\mathrm{CEO}$ hospitalization events}

Our findings so far offer strong indication that CEO education is positively associated with firms' electricity efficiency. Our baseline estimates included a host of confounding factors to rule out concerns of omitted factors. Nevertheless, interpreting our results causally remains problematic due to well-known concerns of endogenous matching between CEOs and firms (e.g. Custodio and Metzger 2014). As Fee et al. (2013) pointed out, endogeneity in the formation and termination of CEO-firm matches hinders the interpretation of existing studies that have used CEO turnover to understand the effect of managerial styles on corporate outcomes.

To alleviate this concern, we use an identification strategy based on CEO hospitalization events. While we acknowledge that the rarity of hospitalization events restricts the analysis to a small sample, this approach has some advantages. First, they occur more frequently than most of the other CEO shocks (e.g. sudden death) used in the previous literature while being largely exogenous to firm outcomes. Bennedsen et al. (2018) provide evidence that reduces the concern of reverse causality, according to which past firm performance may affect the likelihood of hospitalization. ${ }^{11}$ By altering CEO exposure while keeping constant the match between a CEO and its company, hospitalizations enable us to add to our baseline model in Table 4 both firm and CEO fixed effects, which reduce omitted factor biases coming from unobserved individual heterogeneity. Second, while CEO shocks such as sudden death have only a binary variation, hospitalization events have different duration that varies across CEOs; this heterogeneity can be

\footnotetext{
11 To confirm this result in our sample, we estimate a logit regression where the hospitalization is the dependent variable and the main explanatory variable is the change in operating profits to assets between two years and one year prior to the hospitalization event. Results do not show any significant effect of declining performance on the likelihood of hospitalization, and thus mitigate the reverse causality concern that CEOs tend to be hospitalized as a result of worse business conditions.
} 
exploited to estimate the impact of CEO presence at the firms. Third, even though most hospitalization spells are short, the absence from the office is typically much longer: Bennedsen et al. (2018) find that, on average, when an employee is hospitalized from 1 to 3 days the days of absence are 23, and when an employee is hospitalized from 4 to 5 days the days of absence are 39. For senior managers the respective figures are 13 and 27 days. Collectively, these findings indicate that even short spells of CEO hospitalization can lead to a significant decrease in the effective work hours.

The hospitalization of highly educated CEOs may lower current energy use through at least two channels. The first relates hospitalization events to managerial capacity. Environmental projects typically rest on cognitively demanding tasks that require changes in existing routines and novel recombination of existing approaches. Thus, these projects require top-management inputs in formulation, implementation and monitoring. When highly-educated CEOs are hospitalized there is a sudden lack of leadership resources which impairs energy-related projects, in particular if other top managers have to cover up for the absent CEO on the part of the CEO job that is not related to energy projects. Furthermore, there may be delays in restoring environmental initiatives for at least two reasons: (1) the hospitalized CEO may need a personal recovery that extends beyond the actual hospitalization period; (2) when the CEO is back to work, his/her priorities will be on catching up with the day-to-day management while the environmental projects may be put aside for some time.

The second channel relates to the fact that health shocks increase key personal risk in the firm, which in turn affects the behavior of the CEO and the stakeholders of the firm. The CEO may be spending effort and time on his/her current and future well-being and may start considering retiring or changing job. This process likely takes focus away from the most 
complicated activities, which include energy-preserving projects. It also may reduce a CEO's ability and incentives to monitor the activities of the company, and thus weakens employees' incentive to work hard on energy-saving initiatives. External stakeholders might perceive that the CEO may not be around forever or that he/she may not be able to exercise leadership. Customers and suppliers may have reduced incentives to invest in relationship-specific activities with the firm, which will temporarily reduce the resources available to energy-related projects.

Generally, we expect the effect of hospitalization to be different from that of a vacation because vacations are planned (and often in periods where most other employees take vacation) whereas the length and timing of hospitalization and recovery periods are less planned and often come without warning. Bennedsen et al. (2018) document that CEO hospitalization events induce a substantial drop in a firm's operating efficiency: 10 days of hospitalization reduces firm operating profitability with 5.8 pct. from its mean. ${ }^{12}$

Our data source for this analysis is the National Patient Register, which contains all public and private secondary health care interactions in Denmark. ${ }^{13}$ Using this data, we count the days that the CEOs were hospitalized in the year up to and in the current year. As Table 5 shows, out of the total 2,491 firm-year observations there are 250 firm-years (amounting to $10 \%$ of the total number of firm-year observations) in which a CEO has been hospitalized for at least one day within the current and past years. The table also shows that CEO hospitalization events vary in both the intensive and the extensive margins, i.e., the occurrence and duration of hospitalizations.

\footnotetext{
12 Comparing the size of this coefficient with ours is not straightforward due to the fact that a CEO may not optimize energy consumption in the same way as profits. Indeed, we expect that during periods of CEO hospitalization profitability becomes a major concern since the firm seeks to reduce any drop in profit that may harm its competitive ability. During these turbolent periods, environmental projects may be neglected or put aside, and this may explain the larger drop on energy efficiency.

13 The vast majority of hospitalizations are managed by the public healthcare system. Approximately $95 \%$ of the hospital spending in Denmark is financed through public expenditures.
} 
Moreover, as further validation of our approach, the table highlights that hospitalizations do not vary significantly across the CEOs' educational levels. ${ }^{14}$

Insert Table 5 about here

We regress the main dependent variable of Table 4 on the interaction term between hospitalization length and CEO's educational attainment keeping the firm- and CEO-level controls of our previous specification. As shown in Table 6, Column (1), the interaction between CEO hospitalization and holding an undergraduate degree is not significantly different from the baseline (i.e. CEOs with non-college education). By contrast, the interaction between CEO hospitalization and holding an advanced degree is positive and statistically significant.

To validate our result, in Column (2) to (4) we show the findings obtained scaling electricity by fixed assets, gross profits and total assets, respectively. Moreover, in Table 7 we estimate the effect of hospitalization on three different subsamples depending on the level of CEO education. Again, we employ four alternative dependent variables to verify the robustness of our findings. Consistent with our previous findings, CEO hospitalization does not have any significant effect on electricity efficiency when the CEO has low to medium education. However, when the CEO holds an advanced degree, the coefficient of CEO hospitalization becomes significant. Economically, the coefficients indicate that for an additional day a highly educated CEO spends in the hospital, the electricity efficiency of his/her firm drops by $7 \%$ to $9 \%$. While this magnitude may seem large, it is worth keeping in mind that hospitalization events have broader consequences for a CEO's effort provision: each day of hospitalization is surrounded by

\footnotetext{
${ }^{14}$ While our data sources contain information on the primary medical condition, we are unable to exploit this information due to a small sample size.
} 
a period of significantly reduced workload implying that the count of hospital days corresponds to much longer absence spells. Furthermore, there may be urgent day-to-day management to catch up with once the CEO returns, which reduces the time available for energy-saving projects. $^{15}$

Insert Table 6 about here

Insert Table 7 about here

Trying to improve the causal interpretation of our finding, we conduct a placebo test where we estimate the effect of future CEO hospitalization on current electricity consumption. In Table 8 we replace the baseline hospitalization variable with a measure of hospitalization events, which take place either one year or two years after the date of the dependent variable. As shown, none of the interactions between future hospitalization and CEO education has a significant effect on current electricity efficiency.

Insert Table 8 about here

\subsection{Robustness analysis}

In this section, we start by addressing the concern that CEO education is correlated with other factors associated with CEO skills, which may in turn be correlated with electricity efficiency.

\footnotetext{
15 The distribution of hospitalization days in Table 5 suggests that we are mostly capturing the effect of changes in the low end of the distribution. Thus, we cannot speak of very long hospitalization periods - even if we expect them to command large effects since long hospitalizations will likely trigger CEO replacement, retirement or death.
} 
CEO compensation tends to be higher for CEOs that have more skills and experience. Additionally, there is a positive association between CEO pay and education (see e.g. Custodio et al. 2013 on the MBA premium for US CEOs), which makes executive pay a relevant omitted factor potentially biasing our analysis. To account for this challenge, we add a control measuring the logarithm of CEO total compensation. Results in Columns (1) of Table 9 show that CEO compensation is positively associated with firms' electricity efficiency, perhaps consistent with the view that better-paid CEOs have a broader skill set. Nevertheless, we find that the coefficient of CEO education remains economically and statistically significant.

Insert Table 9 about here

CEO ownership may affect the incentives to manage the company efficiently for the long run. In this case, greater CEO equity holdings will extend the time-horizon in managerial decision-making making the firm more focused on long-term sustainable goals rather than shortterm financial results. Due to data limitations, we are unable to estimate separately the effects of long-term equity-based and short term pay items in the CEO's pay package. However, we can control for equity alignment by including a dummy equal to one if the CEO is also a significant shareholder of the firm (i.e. he/she owns at least $5 \%$ of the equity capital). Results reported in Column (2) of Table 9 confirm that CEO education is positively associated with energy efficiency even after controlling for CEO ownership. Lastly, in Column (3) we show that the positive association between CEO education and electricity efficiency is robust to the joint inclusion of CEO pay and CEO equity ownership as controls. ${ }^{16}$

\footnotetext{
${ }^{16}$ A related question would be about the difference of CEO education for publicly traded and private companies. Unfortunately, we do not have publicly traded firms in our sample to make this comparison.
} 
So far, we have employed electricity as main energy input. To generalize our findings, we operationalize the dependent variable using other relevant energy sources such as water and gas consumption. These items are again normalized using employees. Columns (1)-(2) of Table 10, which provide the estimates obtained using these ratios as dependent variables, confirm that CEOs with longer education manage more energy-efficient firms.

Next, we use alternative standardization methods. Columns (3)-(5) of Table 10 show the results obtained using as dependent variable: (1) the logarithm of electricity over profits; (2) the logarithm of electricity over fixed assets; (3) the logarithm of electricity over pre-tax earnings. As shown, the coefficient of CEO education is significant across all columns. We also follow an alternative computation of the dependent variable by converting $\mathrm{kWh}$ and natural gas to British Thermal Units (BTU) to obtain a common measure for both energy inputs. The BTU is defined as the amount of heat required to raise the temperature of one pound of water by one degree of Fahrenheit. We apply the standard conversion rate of $1 \mathrm{kWh}=3,412.14 \mathrm{BTU}$ and $1 \mathrm{~m}^{3} \mathrm{Natural}$ Gas $=36,020.98$ BTU. Finally, we aggregate the BTU stemming from the two different energy inputs at the firm level, divide it by the number of employees and take the logarithm of the resulting values. Results in Column (6) show that an additional year of CEO education lowers energy efficiency by $6 \%$.

Alternatively, following existing work (Jaggi and Freedman 1992; Telle 2006) we construct a ratio that evaluates each firm's energy consumption relative to its peers within a given sub-industry. First, each type of energy consumption is normalized by the firm's number of employees: $e_{i j s t}=\frac{\text { Energy }_{i j s t}}{\text { Employees }_{i j t}}$ where $i$ is the firm, $j$ is the sub-industry, $s$ is the energy source and $t$ is the year. The lower $e_{i j s t}$ the more energy efficient the firm is. To make this ratio comparable, we find the most energy efficient firm in each sub-industry: $e_{\min , j s}=\min _{i=1, \ldots, N ; t=1, \ldots, T}\left(e_{i j s t}\right)$. This 
baseline value is the minimum value of the energy per employee ratio found within each subindustry over the time and for, respectively, electricity, and gas. The sub-industry minimum is now divided by each firm's energy efficiency ratio, to obtain a relative measure of energy efficiency: $E_{i j s}=\frac{e_{m i n, s j}}{e_{i j s}} . E_{i j s}$ ranges from zero to one. The closer to one, the more energy efficient the firm is relative to its peers. As argued, different firms may use different energy sources that can be close substitutes. To ensure that the firms are not just substituting away from one energy source to another, we find the ratios for each energy input and collect them in a common index: Energy index $_{i j t}=\frac{1}{s} \Sigma_{s=1}^{S} E_{i j s}$. Using this ratio, instead of the absolute values, has the advantage that it ranks the firm's energy efficiency within the sub-industry unambiguously. The downside is that it makes it more complex to interpret the regression coefficients. In our computation, both energy sources (electricity and gas) have equal weights. ${ }^{17}$ Unfortunately, the observation number falls significantly, since only firms with information on both the energy variables can be used to compute the index. Results in Column (7) show that CEO education raises a firm's energy efficiency relative to the industry benchmark.

In the next step of our robustness analysis, we account for sectoral heterogeneity in a more fine-grained way. First, we replace the industry classification of our baseline specification (based on 23 industries and effectively partitioning our manufacturing firms in 7 sub-industries) with a classification based on 53 industries (partitioning our manufacturing firms in 17 subindustries). Second, we use an even more detailed classification based on 111 different industries (partitioning our manufacturing firms in 34 sub-industries). Results in Columns (8)-(9) show the results obtained using these more detailed sets of industry dummies. As shown, our findings remain economically and statistically significant.

\footnotetext{
${ }^{17}$ The results are robust to excluding water consumption from the index.
} 
Finally, in Column (10) we estimate our regression separately for the subsample of the most energy-intensive industries (i.e. the two industries with the highest average of the dependent variable computed across all firms). Our results indicate that the effect of CEO education on energy efficiency is economically stronger than the one estimated using the full sample.

Insert Table 10 about here

\subsection{CEOs' field of study}

So far, we have shown that CEO education is associated with energy efficiency. Bloom et al (2010) show a positive association between managerial practices and firms' energy efficiency. This perspective suggests that our findings can be driven by holding degrees in specific fields, such as business studies, which endow CEOs with skills and training in managing firms with fewer energy inputs. Relatedly, CEOs with technical background may have a deeper understanding of products and production units, and may therefore be able to increase a firm's production efficiency.

To delve into the effect of the fields of study, we divide CEOs' educational achievements into four different categories. The first is "short education", which contains all educational degrees lower than college, whereas we divide all "long education" degrees (i.e. undergraduate or higher) into three groups: (1) business (including economics and management); (2) technical (including engineering and natural sciences degrees); and (3) other fields (including humanities, legal studies and so on). As mentioned in Section 2.3, the majority of CEOs with long education did their studies in business $(38 \%)$ or technical-oriented fields $(49 \%)$, while about $13 \%$ of them hold a degree in other disciplines. 
We estimate the model in Table 4 replacing the continuous measure of a CEO's years of education with this categorical variable for the fields of study taking four values (short education is used as baseline group). Table 11 indicates that relative to CEOs with short education, only CEOs with long education in business-related degrees experience a greater electricity efficiency (from $45 \%$ to $51 \%$ depending on the specification, and significant at the $1 \%$ level) while the coefficients for CEOs holding long education in technical fields or other fields are not statistically different from zero. These results provide some support for the managerial practice view, which suggests that CEOs with advanced education in management-related disciplines should leave a larger imprint on firms' energy efficiency.

Insert Table 11 about here

\section{CEO education, environmental attitude and personal choices}

Our analysis so far shows a positive association between CEO education and firms' energy efficiency. As we have argued, this result can be attributable to the fact that more educated managers embrace managerial styles that blend corporate efficiency and respect for the environment. In this section, we test whether $\mathrm{CEO}$ education is associated with a greater awareness of climate changes and, in turn, with a greener attitude in personal decisions.

\subsection{CEO education and the perception of climate change}

We start by studying the relationship between CEO education and individual perception of climate change threats. Measuring preferences toward the environment is challenging. Leveraging on the growing popularity of survey methods in economics (e.g. Bloom and Van Reenen 2007), 
recent studies have adopted questionnaires to elicit pro-environment preferences (e.g. Videras et al. 2012). To address our research question, in collaboration with Statistic Denmark in 2015 we sent a questionnaire to approximately 55,000 Danish CEOs. We received answers from 13,590 CEOs, yielding a response rate of a little over $25 \%$. The survey questions were about values regarding political preferences and cultural values. Importantly, the survey also contained a question asking "Following the current trend, are we going to experience a climate catastrophe in the near future?" Possible responses are: 1=Agree a lot; 2=Agree; 3=Neither nor; 4=Disagree, $5=$ Disagree a lot. We use the response to this question as a measure of CEOs' environmental awareness (greater values correspond to weaker environmental concerns). The 11,901 CEOs that answered this question are, on average, close to climate neutral (with an average response of 2.9). While the survey data is available for a larger sample, in the next empirical analyses we employ the subsample of approximately 5,000 CEOs with available information on the CEO and the education of their parents (which we will later use as an instrument for CEO education). We apply this restriction also when we use OLS, in order to estimate OLS and 2SLS on the same sample.

We start by estimating a regression in which the dependent variable is the measure of climate change concerns ranging from 1 to 5 . Given the ordered nature of such variable, we employ ordered logit regressions. The key explanatory variable measures a CEO's years of education. Results, reported in the first column of Panel A, Table 12, show that CEO education has a negative effect on the likelihood of stating weaker climate change concerns; in other words, longer education makes CEOs more concerned about climate change. To reduce omitted factor problems, we control for the CEO age, gender, and the logarithm of income. Results, reported in the second column of Panel A, are largely consistent with our previous estimates. 
To establish causality, we use a two-stage least square regression. To this end, we follow the educational literature and employ the education of a CEO's father and mother as instrumental variables (see Hoogerheide et al. 2012 for a review). The validity condition maintains that these instruments are significantly associated with $\mathrm{CEO}$ education. We validate this condition in the first-stage regression reported in the left part of Panel B, Table 12: the education of both a CEO's mother and father has a positive and 1\% significant effect on CEO education. The exclusion restriction maintains that parents' education does not have a direct effect on CEO's climate change concerns other than via the direct effect of CEO education. The primary factor that may invalidate this condition is $\mathrm{CEO}$ income: CEOs coming from more educated (and arguably wealthier) parents may also be less financially constrained (due e.g. to intergenerational transfer or resources) and this may influence a CEO's environmental preferences. To mitigate this concern, our specification controls for CEO income. ${ }^{18}$ Another relevant source of variation comes from the family environment in which the CEO grew up: growing up with better educated parents may influence the CEOs' environmental preferences not necessarily via their education but directly via parents' environmental preferences. To alleviate this concern, we should ideally control for parents' environmental preferences. While we do not have direct questions about parents' green attitude, we can use our survey data to control for a host of cultural factors related to the family environment in which the CEOs grew up. ${ }^{19}$ In particular, we control for two variables measuring how religious the CEOs' upbringing was, and

\footnotetext{
${ }^{18}$ In untabulated checks, we also verify that our results are robust to the inclusion of a dummy equal to one if any of the parents have or have had a managerial position in the same firm of the son or daughter (the focal CEO of our analysis). This check is useful to mitigate the concern that parents' education can be correlated with offspring's education (needed for our analysis) but also have a direct effect on offspring's green attitude due to learning or imitation of parents' green managerial style.

${ }^{19} \mathrm{It}$ is important to notice that the average age of our CEOs is 53 years, so the majority of them were children in the 60 and early 70s. Before the oil crisis in 1974, there was, in general, little environmental awareness in Denmark. This supports in itself the claim that CEOs' green awareness is not directly correlated with parents' green awareness after we control for parents' education.
} 
the political orientation in the CEOs' childhood household. These two variables can be used as proxies for climate change views, since religious and political views have been shown to correlate with climate change concerns (e.g. Biel and Nilsson 2014; Stanley et al. 2017; Hoffarth and Hodson 2016). Hence, controlling for these variables partly alleviates concerns about the endogenous transmission of parental education to CEO environmental preferences.

The lower panel of Panel B presents the second stage regression, in which the key explanatory variable is the instrumented value of CEO education together with the controls of our baseline specification. As shown, the results are consistent with our previous insights: CEO education has a positive and $1 \%$ significant effect on climate change concerns. ${ }^{20}$

Insert Table 12 about here

4.2. CEO education and environmental choices: Evidence from cars

The previous section shows that CEO education is positively associated with awareness of climate change issues. But does education make CEOs greener when it comes to allocation of personal resources and decision-making over real outcomes? We address this question using data on CEOs' cars. The Motor Vehicle Register (DMRB) contains extensive information on every motor vehicle registered in a Danish household or company. The register is updated whenever a vehicle undergoes a transaction (e.g. new purchase, change of ownership, scrapping etc.). Given our focus on personal lifestyle, we only focus on passenger cars (excluding commercial vehicles). The cars are all associated with the owner's individual identification number. If the car is owned by a company but used by the $\mathrm{CEO}$, then the company identification number is registered as the

\footnotetext{
20 The table also shows that age and being a male significantly decrease climate concerns, which is in line with previous studies (e.g. Eisler et al. 2003).
} 
owner, but the CEO identification number is registered as the user. We are therefore able to construct a complete map of the cars owned and used by Danish CEOs. Our data contain information on cars' fuel type, fuel efficiency (kilometers per liter of fuel), weight and classification (e.g. 2 or 4-wheel drive). We focus on the universe of Danish CEOs in 2013, and on the subsample of CEOs included in our survey. Summary statistics for both samples are reported in Table 13.

Insert Table 13 about here

In our regression analysis, the first dependent variable is the logarithm of kilometers per liter of fuel (greater values correspond to more environment-friendly cars). One potential violation of this argument is represented by diesel engines, which are normally considered worse for the environment but at the same time makes a car run longer per liter. To avoid this confounding effect, we control for a dummy equal to one for diesel cars, and zero otherwise. ${ }^{21}$ We also control for the weight of the cars and therefore estimate the environmental margin of car choices within a given class of car size. Additionally, we control for the CEO-level characteristics employed in the previous section (namely gender and age, but also CEO income that may affect car choice via budget constraints). To account for the confounding effect of a CEO's area of residence (in urban vs. rural areas) we also control for a dummy equal to one if the CEO lives in one of the five largest Danish municipalities, and zero otherwise.

We employ both OLS and 2SLS using parents' education as instrumental variables. Results in Columns (1)-(2) of Table 14, Panel A, indicate that CEO education has a significant and positive effect on the green efficiency of his/her car. We validate this finding using an

\footnotetext{
${ }^{21}$ Even though diesel cars drive longer per liter of fuel, they pollute more than gasoline cars (Anenberg et al. 2017).
} 
alternative dependent variable, i.e. a dummy equal to one for electric cars and zero otherwise. Driving an electric car is often perceived as a strong environmental commitment. Column (3) shows that more educated CEOs are significantly more likely to own electric cars. The remaining part of the table validates this result using different subsamples. In Columns (4)-(5), we use the subsample of non-married CEOs to evaluate whether their car choice depends on their family situation. Higher education is positively associated with car efficiency in the OLS specification. The coefficient remains positive and large in the 2SLS specification, though the coefficient is less precise.

In Panel B of Table 14, we employ the CEOs covered in the survey discussed in Section 4.1. Again, the results are consistent with our main finding: highly educated CEOs choose more environmental-friendly cars. Using this latter sample makes us able to control for how religious the CEOs' upbringing was, and the political orientation in the CEOs' childhood household (similar to what we did in Section 4.1). As the table shows, our results are robust to the inclusion of these additional variables as well as to the use of a 2SLS regression.

Insert Table 14 about here

\section{Conclusion}

Understanding the drivers of environmental decisions is central to designing effective policies that mitigate the impact of firm actions on natural resources. We contribute to the growing literature on the implications of top executives' human capital by studying how CEO education shapes environmental attitudes in corporate decision-making. 
Estimating a wide array of regressions on a panel dataset of Danish firms from 1996 to 2012, we deliver the following findings. First, we find a positive association between CEO education and firms' energy efficiency: better educated CEOs use significantly less energy inputs (electricity and gas) per employee. Second, we seek to establish the causal direction of our findings by using CEO hospitalization events, which generate temporary and arguably exogenous separations between CEOs and firms without changing the matching between the two. Third, we estimate the effects of long education in different fields showing a positive association between electricity efficiency and CEO advanced education in business-related fields. Fourth, using a comprehensive survey on individual values and preferences, we show that highly educated CEOs exhibit stronger personal concerns for climate change. They are also significantly more likely to own environment-friendly vehicles, such as fuel-efficient cars and electric cars.

Taken together, our results suggest that CEO education brings about a management style that can reconcile financial performance with environmental preservation. 


\section{References}

1. Adams R. and Ferreira D. 2009. Women in the boardroom and their impact on governance and performance. Journal of Financial Economics 94, 291-309.

2. Anenberg S.C., Miller J., Minjares R., Du L., Henze D.K., Lacey F., Malley C.S., Emberson L., Franco V., Klimont Z. and Heyes C. 2017. Impacts and mitigation of excess diesel-related $\mathrm{NO}_{\mathrm{x}}$ emissions in 11 major vehicle markets. Nature 545, 467-471.

3. Amiraslani H., Lins K., Servaes, H. and Tamayo A. 2017. A matter of trust? The bond market benefits of corporate social capital during the financial crisis. Working paper.

4. Amore M.D. and Bennedsen M. 2016. Corporate governance and green innovation. Journal of Environmental Economics and Management 75, 54-72.

5. Barker V.L. and Mueller G.C. 2002. CEO characteristics and firm R\&D spending. Management Science 48, 782-801.

6. Bennedsen M., Perez-Gonzalez F. and Wolfenzon D. 2018. Evaluating the impact of the boss: Evidence from CEO hospitalization events. Journal of Finance, forthcoming.

7. Bertrand M. and Schoar A. 2003. Managing with style: The effect of managers on firm policies. Quarterly Journal of Economics 118, 1169-1208.

8. Biel A. and Nilsson A. 2014. Religious values and environmental concern: Harmony and detachment. Social Science Quarterly 86, 178-191.

9. Black S., Dereveuz P., Lundborg P. and Majlesi K. 2018. Learning to take risks? The effect of education on risk-taking in financial markets. Review of Finance, forthcoming.

10. Bloom N. and Van Reenen J. 2007. Measuring and explaining management practices across firms and countries. Quarterly Journal of Economics 122, 1351-1408.

11. Bloom N. Genakos C., Martin R. and Sadun R. 2010. Modern management: Good for the environment or just hot air? Economic Journal 120, 551-572.

12. Boyd G. and Curtis M. 2014. Evidence of an "Energy-management gap" in the US manufacturing: Spillovers from firm management practices to energy efficiency. Journal of Environmental Economics and Management 68, 463-479.

13. Brand J. 2010. Civic return to higher education: A note on heterogeneous effects. Social Forces 89, 417-433.

14. Brunnermeier S. and Cohen M. 2003. Determinants of environmental innovation in U.S. manufacturing industries. Journal of Environmental Economics and Management 45, 278-293.

15. Card D. 2001. Estimating the return to schooling: Progress on some persistent econometric problems. Econometrica 69, 1127-1160.

16. Cherry T.L., Kallbekken S. and Kroll S. 2017. Accepting market failure: Cultural worldviews and the opposition to corrective environmental policies. Journal of Environmental Economics and Management 85, 193-204.

17. Cole S., Paulson A. and Shastry G.K. 2014. Smart money: The effect of education on financial outcomes. Review of Financial Studies 27, 2022-2051.

18. Cronqvist H., Makhija A. and Yonker S.E. 2012. Behavioral consistency in corporate finance: CEO personal and corporate leverage. Journal of Financial Economics 103, 20-40.

19. Cronqvist H. and Yu F. 2017. Shaped by their daughters: Executives, female socialization, and corporate social responsibility. Journal of Financial Economics, forthcoming.

20. Custodio C. and Metzger D. 2013. How do CEOs matter? The effect of industry expertise on acquisition returns. Review of Financial Studies 26, 2008-2047.

21. Custodio C., Ferreira M. and Matos P. 2013. Generalists versus specialists: Lifetime work experience and chief executive officer pay. Journal of Financial Economics 108, 471-492. 
22. Dai R., Liang H. and Ng L. 2018. Socially responsible corporate customers. Working paper.

23. Dee T.S. 2004. Are there civic returns to education? Journal of Public Economics 88, $1697-$ 1720.

24. Deng X., Kang J. and Low B.S. 2015. Corporate social responsibility and stakeholder value maximization: Evidence from mergers. Journal of Financial Economics 110, 87-109.

25. Dittmar A. and Duchin R. 2016. Looking in the rearview mirror: The effect of managers' professional experience on corporate financial policy. Review of Financial Studies 29, 565602.

26. Eisler A.D., Eisler H. and Yoshida M. 2003. Perception of human ecology: Cross-cultural and gender comparisons. Journal of Environmental Psychology 23, 89-101.

27. Falato A., Li D. and Milbourn T. 2015. Which skills matter in the market for CEOs? Evidence from pay for CEO credentials. Management Science 61, 2845-2869.

28. Fee C.E., Hadlock C. and Pierce J. 2013. Managers with and without style: Evidence using exogenous variation. Review of Financial Studies 26, 567-601.

29. Flammer C. 2015. Does corporate social responsibility lead to superior financial performance? A regression discontinuity approach. Management Science 61, 2549-2568.

30. Fernandez-Kranz D. and Santaló J. 2010. When necessity becomes a virtue: The effect of product market competition on corporate social responsibility. Journal of Economics and Management Strategy 19, 453-487.

31. Ferrell A., Hao L. and Renneboog L. 2016. Socially responsible firms. Journal of Financial Economics 122, 585-606.

32. Friedman M. 1955. The role of government in education. In Economics and the Public Interest. Edited by Solo R.A. Rutgers University Press: New Jersey.

33. Hoffarth M. and Hodson G. 2016. Green on the outside, red on the inside: Perceived environmentalist threat as a factor explaining political polarization of climate change. Journal of Environmental Psychology 45, 40-49.

34. Hoogerheide L., Block J.H. and Thurik R. 2012. Family background variables as instruments for education in income regressions: A Bayesian analysis. Economics of Education Review 31, 515-523.

35. Huang J., van den Brink H. and Groot W. 2009. A meta-analysis on the effect of education on social capital. Economics of Education Review 28, 454-464.

36. Hong H. and Kacperczyk M. 2009. The price of sin: The effects of social norms on markets. Journal of Financial Economics 93, 15-36.

37. Jaffe A. and Palmer K. 1997. Environmental regulation and innovation: A panel data study. Review of Economics and Statistics 79, 610-619.

38. Jaggi B. and Freedman M. 1992. An examination of the impact of pollution performance on economic and market performance: pulp and paper firms. Journal of Business Finance \& Accounting 19, 697-713.

39. Liang H. and Renneboog L. 2017. On the foundations of corporate social responsibility. Journal of Finance 72, 853-910.

40. King T., Srivastav A. and Williams J. 2016. What's in an education? Implications of CEO education for bank performance. Journal of Corporate Finance 37, 287-308.

41. Knittel C., Miller D. and Sanders N. 2016. Caution, drivers! Children present: Traffic, pollution, and infant health. Review of Economics and Statistics 98, 350-366. 
42. Kock C.J., Santaló J. and Diestre L. 2012. Corporate governance and the environment: What type of governance creates greener companies? Journal of Management Studies 49, 492 514.

43. Krueger A. and Lindahl M. 2001. Education for growth: Why and for whom? Journal of Economic Literature 39, 1101-1136.

44. Kruger P. 2015. Corporate goodness and shareholder wealth. Journal of Financial Economics 115, 304-329.

45. Lu Y., Ray S. and Teo M. 2016. Limited attention, marital events and hedge funds. Journal of Financial Economics 122, 607-624.

46. Lyubich E., Shapiro J. and Walker R. 2018. Regulating mismeasured pollution: Implications of firm heterogeneity for environmental policy. Working paper.

47. Malmendier U. and Tate G. 2005. CEO overconfidence and corporate investment. Journal of Finance 60, 2661-2700.

48. Malmendier U. and Tate G. 2008. Who makes acquisitions? CEO overconfidence and the market's reaction. Journal of Financial Economics 89, 20-43.

49. Martin R., Muuls M., de Preux L. and Wagner U. 2012. Anatomy of a paradox: Management practices, organizational structure and energy efficiency. Journal of Environmental Economics and Management 63, 208-223.

50. Meyer A. 2015. Does education increase pro-environmental behavior? Evidence from Europe. Ecological Economics 116, 108-121.

51. Miller D., Xu. J. and Merhotra V. 2015. When is human capital a valuable resource? The performance effects of Ivy League selection among celebrated CEOs. Strategic Management Journal 36, 930-944.

52. Milligan K., Moretti E. and Oreopoulos P. 2004. Does education improve citizenship? Evidence from the United States and the United Kingdom. Journal of Public Economics 88, 1667-1695.

53. Nesta L., Vona F. and Nicolli F. 2014. Environmental policies, competition and innovation in renewable energy. Journal of Environmental Economics and Management 67, 396411.

54. Oreopoulos P. 2007. Do dropouts drop out too soon? Wealth, health and happiness from compulsory schooling. Journal of Public Economics 91, 2213-2229.

55. Popp D. 2002. Induced innovation and energy prices. American Economic Review 92, 160 180.

56. Putnam R.D. 1995. Tuning in, tuning out: The strange disappearance of social capital in America. Political Science and Politics 28, 664-83.

57. Servaes H. and Tamayo A. 2013. The impact of corporate social responsibility on firm value: The role of customer awareness. Management Science 59, 1045-1061.

58. Scherer F.M. and Huh K. 1992. Top managers education and R\&D investment. Research Policy 21, 507-511.

59. Shapira R. and Zingales L. 2017. Is pollution value-maximizing? The DuPont case. Working paper.

60. Stanley S., Wilson M. and Milfont T. 2017. Exploring short-term longitudinal effects of right-wing authoritarianism and social dominance orientation on environmentalism. Personality and Individual Differences 108, 174-177.

61. Telle K. 2006. "It pays to be green" - A premature conclusion? Environmental \& Resource Economics 35, 195-220. 
62. Videras J., Owen A.L., Conover E. and Wu S. 2012. The influence of social relationships on pro-environment behaviors. Journal of Environmental Economics and Management 63, 35-50.

63. Volland B. 2017. The role of risk and trust attitudes in explaining residential energy demand: Evidence from the United Kingdom. Ecological Economics 132, 14-30.

64. Yan S. and Eskeland G.S. 2018. Greening the vehicle fleet: Norway's $\mathrm{CO}_{2}$-differentiated registration tax. Journal of Environmental Economics and Management 91, 247-262.

65. Yim S. 2013. The acquisiveness of youth: CEO age and acquisition behavior. Journal of Financial Economics 108, 250-273. 


\section{Table 1. Summary statistics}

Panels A and B of this table provide firm characteristics for our sample firms for the period 1996-2012. Fixed assets, total assets, gross profits and pretax earnings are expressed in 1,000,000 DKK $=150.800 \$$ $=134.500 €$. Capital Intensity is the ratio of a firm's fixed assets (in DKK 1,000) over its number of employees. Employees are the number of employees in the firm. Energy variables are expressed in thousands. Panel $\mathrm{C}$ shows the distribution of observations across manufacturing sub-industries classified according to the 3-digit NACE (the European statistical classification of economic activities).

\begin{tabular}{|c|c|c|c|}
\hline \multicolumn{4}{|l|}{ Panel A. Firm characteristics } \\
\hline & Observations & Mean & Std. dev. \\
\hline Total assets & 2,491 & 341,894 & $1,729,515$ \\
\hline Fixed assets & 2,491 & 209,791 & $1,265,396$ \\
\hline Gross profit & 2,444 & 92,075 & 317,985 \\
\hline Pretax earnings & 2,491 & 30,721 & 182,417 \\
\hline Capital intensity & 2,491 & 1,346 & 1,721 \\
\hline Employees & 2,491 & 168 & 351 \\
\hline \multicolumn{4}{|c|}{ Panel B. Energy-related measures } \\
\hline & Observations & Mean & Std. dev. \\
\hline Electricity, kWh & 2,491 & $4,235.80$ & $6,733.94$ \\
\hline Log(kWh/Employees) & 2,491 & 10.02 & 1.22 \\
\hline Log(kWh/Fixed assets) & 2,491 & 4.00 & 1.41 \\
\hline $\log (\mathrm{kWh} /$ Gross profit $)$ & 2,409 & 4.06 & 1.37 \\
\hline Log(kWh/Pretax earnings $)$ & 1,900 & 5.78 & 1.83 \\
\hline Gas, $\mathrm{M}^{3}$ & 1,527 & $1,817.58$ & 10,200 \\
\hline Log(Gas/Employees) & 1,527 & 7.18 & 2.80 \\
\hline Log(Gas/Fixed assets) & 1,527 & 1.03 & 2.70 \\
\hline $\log ($ Gas/Gross profit $)$ & 1,476 & 1.23 & 2.84 \\
\hline Log(Gas/Pretax earnings ) & 1,159 & 3.00 & 3.00 \\
\hline Water, $\mathrm{M}^{3}$ & 2,737 & 180.65 & 883.16 \\
\hline Log(Water/Employees) & 2,737 & 4.45 & 2.19 \\
\hline Log(Water/Fixed assets) & 2,737 & -1.67 & 2.16 \\
\hline Log(Water/Gross profit) & 2,654 & -1.54 & 2.19 \\
\hline Log(Water/Pretax earnings) & 2,155 & 0.14 & 2.41 \\
\hline
\end{tabular}


Panel C. Industry distribution

Food

Leather and related

Paper products

Chemicals

Other non-metal

Computer and electronics

Electrical equipment

Total

\begin{tabular}{cc} 
Observations & Percent \\
\hline 16 & 0.64 \\
445 & 17.86 \\
71 & 2.85 \\
147 & 5.90 \\
787 & 31.59 \\
92 & 3.69 \\
933 & 37.45 \\
2,491 & 100 \\
\hline
\end{tabular}




\section{Table 2. CEO demographic characteristics}

This table shows the summary statistics for the CEOs of our sample firms. Years of education measures a CEO's years of schooling. Business advanced degree $(\%)$ is the fraction of CEOs with undergraduate or higher education in management or economics degrees. Technical advanced degree (\%) is the fraction of CEOs with undergraduate or higher education in engineering or natural sciences. Other advanced degree $(\%)$ is the fraction of CEOs with undergraduate or higher education outside either technical or business fields. Male CEO is a dummy equal to one for male CEOs and zero for female CEOs. CEO age measures the years of CEO age. $\log (\mathrm{CEO}$ income) is the logarithm of CEO income. CEO ownership is a dummy equal to one if the CEO holds more than $5 \%$ of the firm's equity shares. A complete description of each variable is provided in Table A1.

\begin{tabular}{lccc}
\hline & Observations & Mean & Std. dev. \\
\cline { 2 - 4 } Years of education & 2,491 & 14.95 & 2.47 \\
Business advanced degree $(\%)$ & 2,491 & 0.20 & 0.40 \\
Technical advanced degree (\%) & 2,491 & 0.26 & 0.44 \\
Other advanced degree (\%) & 2,491 & 0.07 & 0.26 \\
Male CEO & 2,491 & 0.98 & 0.15 \\
CEO age & 2,491 & 53.62 & 8.28 \\
Log(CEO income) & 2,418 & 13.84 & 0.75 \\
CEO ownership & 2,491 & 0.08 & 0.27 \\
\hline
\end{tabular}


Table 3. Average firm characteristics by CEO educational level

This table reports the average values of Table 1, Panels A and B, separately for different levels of CEO education.

\begin{tabular}{|c|c|c|c|}
\hline \multicolumn{4}{|l|}{ Panel A. Firm characteristics } \\
\hline & $\begin{array}{c}\text { Non-college } \\
\text { degree }\end{array}$ & $\begin{array}{c}\text { Undergraduate } \\
\text { degree }\end{array}$ & $\begin{array}{l}\text { Master } \\
\text { or } \mathrm{PhD}\end{array}$ \\
\hline Fixed assets & $52,448.73$ & $106,576.50$ & $836,562.60$ \\
\hline Total assets & $103,767.00$ & $190,991.20$ & $1,279,616.00$ \\
\hline Gross profit & $38,352.56$ & $74,145.09$ & $270,324.30$ \\
\hline Pretax earnings & $6,661.97$ & $14,289.49$ & $127,889.10$ \\
\hline Capital intensity & $1,175.43$ & $1,157.27$ & $2,185.23$ \\
\hline Employees & 93.40 & 165.93 & 370.89 \\
\hline \multicolumn{4}{|c|}{ Panel B. Energy-related measures } \\
\hline & $\begin{array}{c}\text { Non-college } \\
\text { degree }\end{array}$ & $\begin{array}{c}\text { Undergraduate } \\
\text { degree }\end{array}$ & $\begin{array}{l}\text { Master } \\
\text { or PhD }\end{array}$ \\
\hline Electricity, kWh & $2,904.57$ & $4,620.42$ & $6,965.50$ \\
\hline Log(kWh/Employees) & 10.16 & 9.89 & 9.90 \\
\hline Log(kWh/Fixed assets) & 4.24 & 3.98 & 3.39 \\
\hline $\log (\mathrm{kWh} /$ Gross profit $)$ & 4.26 & 3.98 & 3.66 \\
\hline Log(kWh/Pretax earnings $)$ & 6.16 & 5.69 & 5.02 \\
\hline Gas, $\mathrm{M}^{3}$ & $1,166.07$ & 805.26 & $1,302.53$ \\
\hline Log(Gas/Employees) & 7.73 & 7.24 & 7.60 \\
\hline Log(Gas/Fixed assets) & 1.66 & 1.22 & 1.07 \\
\hline Log(Gas/Gross profit) & 1.78 & 1.37 & 1.42 \\
\hline Log(Gas/Pretax earnings) & 3.80 & 3.18 & 3.04 \\
\hline Water, $\mathrm{M}^{3}$ & 38.64 & 98.63 & 236.41 \\
\hline Log(Water/Employees) & 4.58 & 4.10 & 4.78 \\
\hline Log(Water/Fixed assets) & -1.35 & -1.78 & -1.74 \\
\hline Log(Water/Gross profit) & -1.34 & -1.80 & -1.46 \\
\hline Log(Water/Pretax earnings) & 0.56 & -0.16 & -0.06 \\
\hline
\end{tabular}




\section{Table 4. CEO education and firms' electricity efficiency}

The dependent variable is the natural logarithm of electricity consumption over the number of employees. The main explanatory variable in Columns (1)-(4), years of education, measures a CEO's years of schooling, whereas the main explanatory variable in Column (5) is a set of dummies measuring the CEO's highest degree, where "No college degree" is the baseline. Male CEO is a dummy equal to one for male CEOs and zero for female CEOs. CEO age measures the years of CEO age. Log(Capital intensity) is the natural logarithm of the ratio of a firm's fixed assets over its number of employees. Asset growth is the growth rate in the firm's total assets, Employees are the number of employees in the firm. Total assets is the logarithm of a firm's total assets. Furthermore, our regressions include 3-digit industry and year dummies. Clustered (firm) standard errors are shown in the parenthesis. ${ }^{* * *} \mathrm{p}<0.01,{ }^{* *} \mathrm{p}<0.05,{ }^{*} \mathrm{p}<0.1$.

\section{Panel A.}

Dependent variable: $\log (\mathrm{kWh} /$ Employees $)$

Years of education

$\frac{(1)}{-0.0738^{* * *}-0 .}$

(2)

(3)

(4)

Male CEO

(0.022)

$(0.022)$

0.0620

(0.193)

$\mathrm{CEO}$ age

$\log$ (Capital intensity)

$-0.0032$

(0.006)

$0.0799 * * *$

$0.0799 *$

$(0.021)$

$-0.1389$

(0.168)

$-0.0052$

(0.006)

$0.2711 * * *$

(0.057)

$-0.0637 * *-0.0546 * *$

$(0.028) \quad(0.028)$

Total assets

Industry dummies

Year dummies

Observations

Adjusted R ${ }^{2}$

\begin{tabular}{cccc} 
& & & $(0.002)$ \\
\hline Yes & Yes & Yes & Yes \\
Yes & Yes & Yes & Yes \\
2,491 & 2,491 & 2,491 & 2,491 \\
0.110 & 0.111 & 0.159 & 0.184 \\
\hline
\end{tabular}

Panel B.

Dependent variable: $\log (\mathrm{kWh} /$ Employees $)$

Undergraduate degree

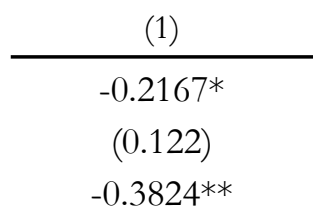

Master or PhD

$-0.3824 * *$

(0.161)

$-0.1415$

(0.163)

$-0.0030$

(0.006)

$\mathrm{CEO}$ age

$0.3324 * * *$

$\log ($ Capital intensity)

(0.059)

Asset growth

$-0.0527 *$

(0.028)

Total assets

$-0.0119 * * *$

Industry dummies

(0.002)

Yes

Yes

2,491

Observations

0.180 


\section{Table 5. CEO hospitalization events}

Each column reports firm-year observations by CEOs' highest degree and by the level of hospitalization days in the current year and the year before. Hospital data are constructed based on records from Statistics Denmark, which reports the number of days that an individual was hospitalized.

\begin{tabular}{lccc}
\hline & $\begin{array}{c}\text { Non-college } \\
\text { degree }\end{array}$ & $\begin{array}{c}\text { Undergraduate } \\
\text { degree }\end{array}$ & $\begin{array}{c}\text { Master } \\
\text { or PhD }\end{array}$ \\
\cline { 2 - 4 } None & 1,026 & 814 & 401 \\
1 day & 50 & 19 & 11 \\
2 days & 20 & 16 & 6 \\
3 days & 14 & 14 & 5 \\
4 days & 9 & 5 & $<5$ \\
5 days & $<5$ & 6 & $<5$ \\
6 days & 9 & $<5$ & $<5$ \\
7 days & $<5$ & $<5$ & $<5$ \\
$\geq 8$ days & 39 & 15 & $<5$ \\
Total & 1,162 & 894 & 435 \\
\hline
\end{tabular}




\section{Table 6. CEO hospitalization and electricity efficiency: Interaction}

The dependent variable is the natural logarithm of electricity consumption over the number of employees (Column 1), fixed assets (Column 2), gross profits ( Column 3) or total assets (Column 4). Days at hospital $[t-1, t]$ measures the hospitalization days of the CEO in the current year and the year before. Undergraduate degree is a dummy equal to one of the CEOs hold an undergraduate degree, and zero otherwise. Master or PhD is a dummy equal to one if the CEOs hold a Master or PhD degree, and zero otherwise. The baseline group is formed by CEOs holding non-college degrees. CEO age measures the years of CEO age. $\log$ (Capital intensity) is the natural logarithm of the ratio of a firm's fixed assets over its number of employees. Asset growth is the growth rate in the firm's total assets Employees are the number of employees in the firm. Total assets is the logarithm of a firm's total assets. Furthermore, our regressions include 3-digit industry and year dummies. Clustered (firm) standard errors are shown in the parenthesis. ${ }^{* * *}$ $\mathrm{p}<0.01, * * \mathrm{p}<0.05, * \mathrm{p}<0.1$.

\begin{tabular}{|c|c|c|c|c|}
\hline Dependent variable: & $\begin{array}{c}\mathrm{Ln}(\mathrm{kWh} / \\
\text { Employees) } \\
\text { (1) }\end{array}$ & $\begin{array}{l}\mathrm{Ln}(\mathrm{kWh} / \\
\text { Fixed } \\
\text { assets }) \\
(2)\end{array}$ & $\begin{array}{c}\mathrm{Ln}(\mathrm{kWh} / \\
\text { Gross } \\
\text { profits }) \\
(3)\end{array}$ & $\begin{array}{c}\text { Ln(kWh/ } \\
\text { Total } \\
\text { assets }) \\
\text { (4) }\end{array}$ \\
\hline Days at hospital $[t-1, t]$ & $\begin{array}{c}-0.0044 \\
(0.010)\end{array}$ & $\begin{array}{c}-0.0044 \\
(0.010)\end{array}$ & $\begin{array}{c}-0.0092 \\
(0.009)\end{array}$ & $\begin{array}{c}-0.0067 \\
(0.011)\end{array}$ \\
\hline Days at hospital $[t-1, t] \times$ Undergraduate Degree & $\begin{array}{l}0.0077 \\
(0.012)\end{array}$ & $\begin{array}{l}0.0076 \\
(0.012)\end{array}$ & $\begin{array}{l}0.0129 \\
(0.011)\end{array}$ & $\begin{array}{l}0.0105 \\
(0.013)\end{array}$ \\
\hline Days at hospital $[t-1, t] \times$ Master or PhD & $\begin{array}{c}0.0887^{* * * *} \\
(0.033)\end{array}$ & $\begin{array}{c}0.0889 * * * \\
(0.033)\end{array}$ & $\begin{array}{c}0.0856^{* *} \\
(0.043)\end{array}$ & $\begin{array}{c}0.0922^{* * *} \\
(0.034)\end{array}$ \\
\hline CEO age & $\begin{array}{c}-0.0039 \\
(0.014)\end{array}$ & $\begin{array}{r}-0.0027 \\
(0.014)\end{array}$ & $\begin{array}{l}0.0138 \\
(0.017)\end{array}$ & $\begin{array}{c}-0.0113 \\
(0.014)\end{array}$ \\
\hline $\log ($ Capital intensity) & $\begin{array}{c}0.2382^{* * *} \\
(0.070)\end{array}$ & $\begin{array}{c}-0.7606^{* * *} \\
(0.070)\end{array}$ & $\begin{array}{c}0.1208^{* *} \\
(0.054)\end{array}$ & $\begin{array}{c}-0.2708^{* * *} \\
(0.050)\end{array}$ \\
\hline Asset growth & $\begin{array}{l}0.0254 \\
(0.025)\end{array}$ & $\begin{array}{l}0.0251 \\
(0.025)\end{array}$ & $\begin{array}{c}-0.0416 \\
(0.042)\end{array}$ & $\begin{array}{c}0.1459^{* *} \\
(0.059)\end{array}$ \\
\hline Total assets & $\begin{array}{l}0.0035 \\
(0.008) \\
\end{array}$ & $\begin{array}{l}0.0034 \\
(0.008) \\
\end{array}$ & $\begin{array}{r}-0.0002 \\
(0.009) \\
\end{array}$ & \\
\hline Firm fixed effects & Yes & Yes & Yes & Yes \\
\hline CEO fixed effects & Yes & Yes & Yes & Yes \\
\hline Year dummies & Yes & Yes & Yes & Yes \\
\hline Observations & 2,491 & 2,491 & 2,401 & 2,491 \\
\hline Adjusted $\mathrm{R}^{2}$ & 0.913 & 0.935 & 0.898 & 0.925 \\
\hline
\end{tabular}




\section{Table 7. CEO hospitalization and electricity efficiency: Subsample analysis}

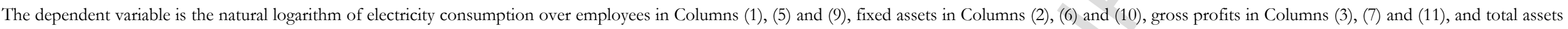

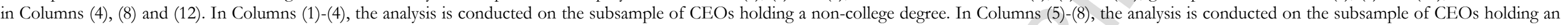

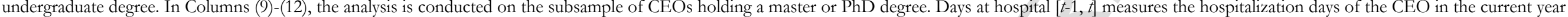

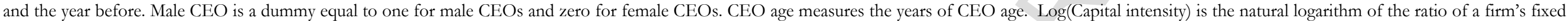

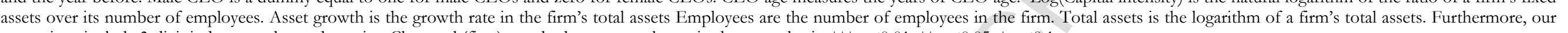
regressions include 3-digit industry and year dummies. Clustered (firm) standard errors are shown in the parenthesis. ${ }^{* * *} \mathrm{p}<0.01,{ }^{* *} \mathrm{p}<0.05,{ }^{*} \mathrm{p}<0.1$.

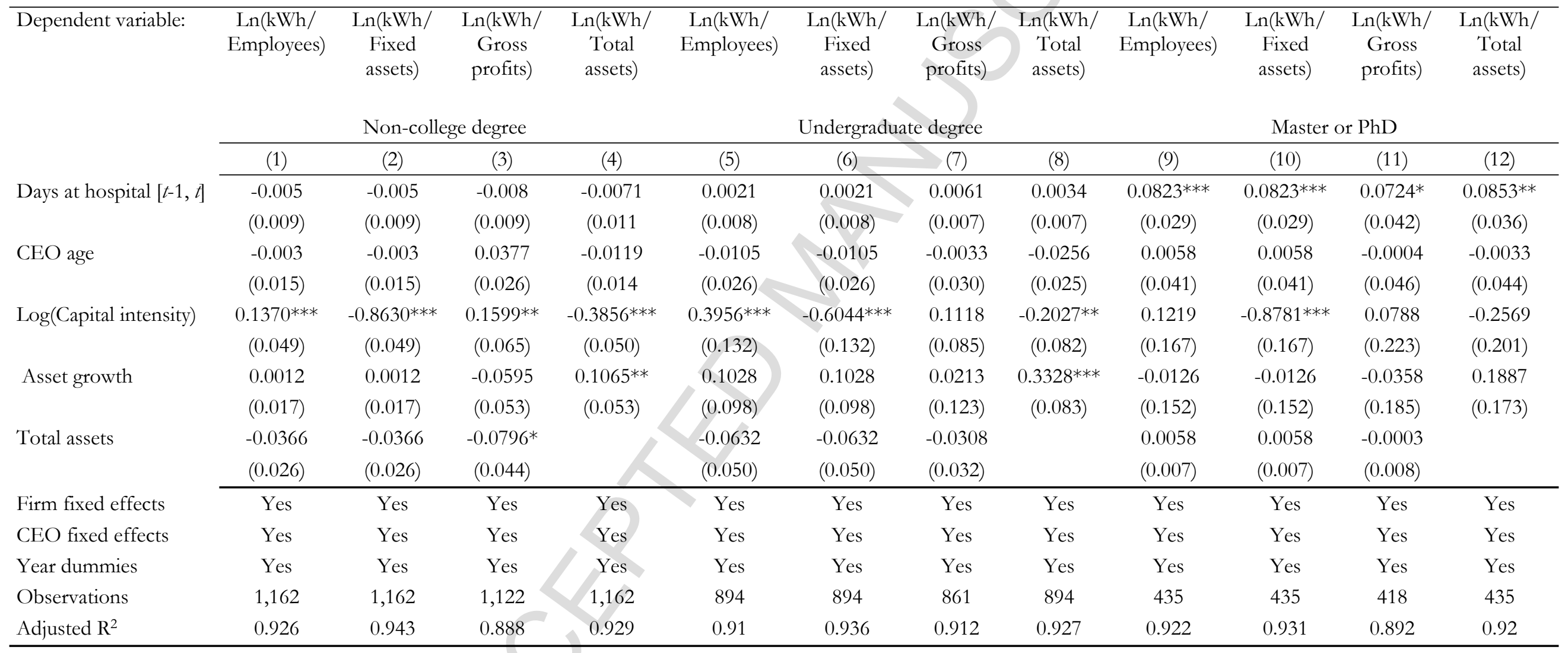




\section{Table 8. Placebo tests: Effect of future hospitalization on current electricity efficiency}

The dependent variable is the natural logarithm of electricity consumption over the number of employees. Days at hospital 1 year ahead (Column 1) and 2 years ahead (Column 2) measure, respectively, the hospitalization days dated one year or two years after the time when the dependent variable is measured. Undergraduate degree is a dummy equal to one of the CEOs hold an undergraduate degree, and zero otherwise. Master or $\mathrm{PhD}$ is a dummy equal to one if the CEOs hold a Master or $\mathrm{PhD}$ degree, and zero otherwise. The baseline group is formed by CEOs holding non-college degrees. CEO age measures the years of CEO age. $\log$ (Capital intensity) is the natural logarithm of the ratio of a firm's fixed assets over its number of employees. Asset growth is the growth rate in the firm's total assets Employees are the number of employees in the firm. Total assets is the logarithm of a firm's total assets. Furthermore, our regressions include 3-digit industry and year dummies. Clustered (firm) standard errors are shown in the parenthesis. ${ }^{* * *} \mathrm{p}<0.01,{ }^{* *} \mathrm{p}<0.05,{ }^{*} \mathrm{p}<0.1$.

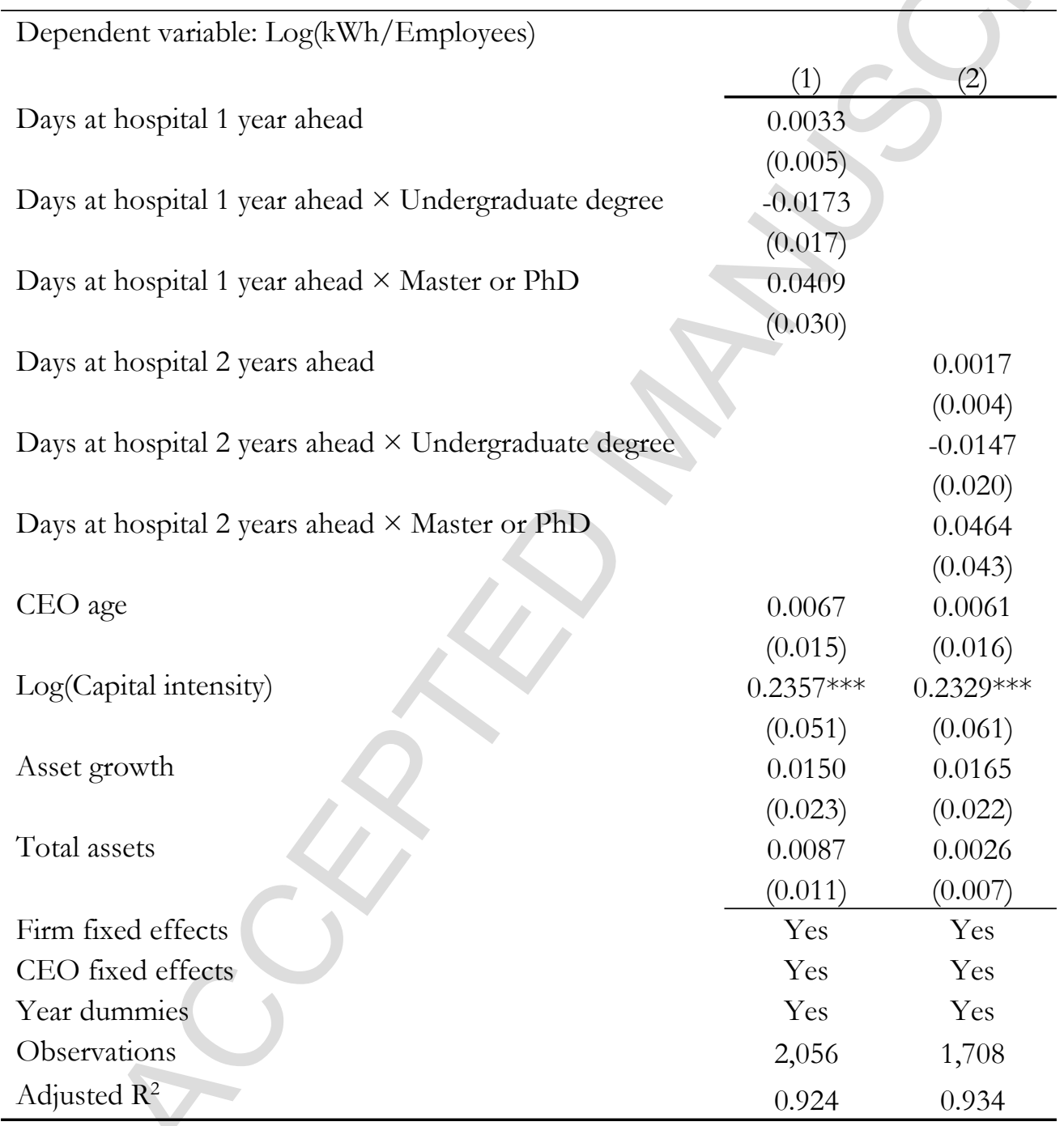




\section{Table 9. Controlling for CEO pay and ownership}

The dependent variable is the natural logarithm of electricity consumption over number of employees. The main explanatory variable in Columns (1)-(4), years of education, measures a CEO's years of schooling. $\log (\mathrm{CEO}$ Income) is the natural logarithm of the CEO yearly income. CEO ownership is a dummy equal to one if the CEO holds more than $5 \%$ of the firm's equity shares. CEO age measures the years of CEO age. $\log$ (Capital intensity) is the natural logarithm of the ratio of a firm's fixed assets over its number of employees. Asset growth is the growth rate in the firm's total assets Employees are the number of employees in the firm. Total assets is the logarithm of a firm's total assets. Furthermore, our regressions include 3-digit industry and year dummies. Clustered (firm) standard errors are shown in the parenthesis. *** $\mathrm{p}<0.01,{ }^{* *} \mathrm{p}<0.05,{ }^{*} \mathrm{p}<0.1$.

\begin{tabular}{|c|c|c|c|}
\hline \multicolumn{4}{|c|}{ Dependent variable: $\log (\mathrm{kWh} /$ Employees $)$} \\
\hline & (1) & (2) & (3) \\
\hline Years of education & $\begin{array}{c}-0.0525^{* * *} \\
(0.020)\end{array}$ & $\begin{array}{c}-0.0609 * * * \\
(0.020)\end{array}$ & $\begin{array}{c}-0.0557^{* * *} \\
(0.020)\end{array}$ \\
\hline $\mathrm{Log}(\mathrm{CEO}$ income $)$ & $\begin{array}{c}-0.1378^{* *} \\
(0.062)\end{array}$ & & $\begin{array}{c}-0.1391 * * \\
(0.061)\end{array}$ \\
\hline CEO ownership & & $\begin{array}{c}-0.3733 * \\
(0.198)\end{array}$ & $\begin{array}{c}-0.3345^{*} \\
(0.179)\end{array}$ \\
\hline Male CEO & $\begin{array}{c}-0.0064 \\
(0.161)\end{array}$ & $\begin{array}{c}-0.0981 \\
(0.166)\end{array}$ & $\begin{array}{r}0.0003 \\
(0.159)\end{array}$ \\
\hline CEO age & $\begin{array}{c}-0.0030 \\
(0.005)\end{array}$ & $\begin{array}{c}-0.0044 \\
(0.005)\end{array}$ & $\begin{array}{c}-0.0023 \\
(0.005)\end{array}$ \\
\hline $\log ($ Capital intensity $)$ & $\begin{array}{c}0.2776^{* * *} \\
(0.059)\end{array}$ & $\begin{array}{c}0.3062^{* * *} \\
(0.057)\end{array}$ & $\begin{array}{c}-0.3345^{*} \\
(0.179)\end{array}$ \\
\hline Asset growth & $\begin{array}{c}-0.0534^{*} \\
(0.027)\end{array}$ & $\begin{array}{c}-0.0568^{* *} \\
(0.028)\end{array}$ & $\begin{array}{c}-0.0464^{*} \\
(0.027)\end{array}$ \\
\hline Total assets & $\begin{array}{c}-0.0113^{* * *} \\
(0.002) \\
\end{array}$ & $\begin{array}{c}-0.0122^{* * *} \\
(0.003) \\
\end{array}$ & $\begin{array}{c}-0.0112^{* * *} \\
(0.002) \\
\end{array}$ \\
\hline Industry dummies & Yes & Yes & Yes \\
\hline Year dummies & Yes & Yes & Yes \\
\hline Observations & 2,483 & 2,556 & 2,483 \\
\hline Adjusted $\mathrm{R}^{2}$ & 0.183 & 0.183 & 0.188 \\
\hline
\end{tabular}




\section{Table 10. Robustness checks}

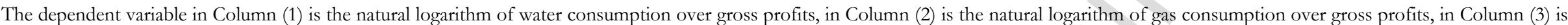

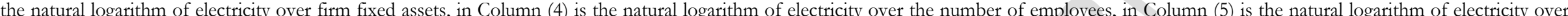

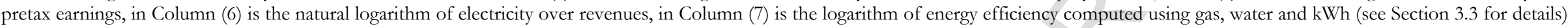

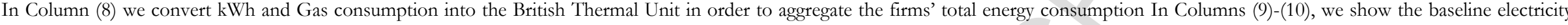

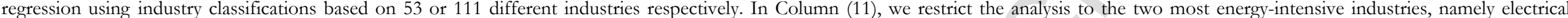

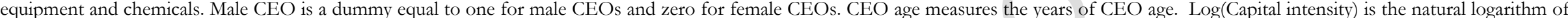

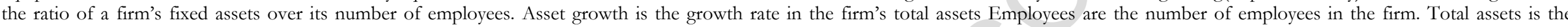

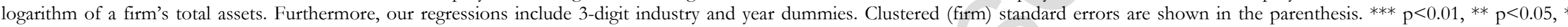
$\mathrm{p}<0.01$.

\begin{tabular}{|c|c|c|c|c|c|c|c|c|c|c|}
\hline \multirow[t]{2}{*}{ Dependent variable: } & $\begin{array}{l}\text { Log(Water/ } \\
\text { Employees) }\end{array}$ & $\begin{array}{c}\text { Log(Gas/ } \\
\text { Employees) }\end{array}$ & $\begin{array}{l}\log (\mathrm{kWh} / \\
\text { Gross } \\
\text { profits })\end{array}$ & $\begin{array}{l}\log (\mathrm{kWh} / \\
\text { Fixed } \\
\text { assets })\end{array}$ & $\begin{array}{c}\log (\mathrm{kWh} / \\
\text { Pretax } \\
\text { earnings })\end{array}$ & $\begin{array}{l}\text { BTU-based } \\
\text { index }\end{array}$ & $\begin{array}{c}\text { Efficiency } \\
\text { (Gas \& } \\
\text { kWh) }\end{array}$ & $\begin{array}{c}\log (\mathrm{kWh} / \\
\text { Employees }) \\
\text { 3-digit }\end{array}$ & $\begin{array}{c}\text { Log }(\mathrm{kWh} / \\
\text { Employees }) \\
\text { 4-digit }\end{array}$ & $\begin{array}{c}\text { Energy- } \\
\text { intensive } \\
\text { subsample }\end{array}$ \\
\hline & $(1)$ & $(2)$ & (3) & (4) & (5) & (6) & $(7)$ & $(8)$ & $(9)$ & $(10)$ \\
\hline \multirow[t]{2}{*}{ Years of education } & -0.0629 & $-0.1668^{* * *}$ & $-0.0712 * * *$ & $-0.0569 * * *$ & $-0.0931 * * *$ & $-0.0634 * *$ & $0.1966^{* * *}$ & $-0.0528^{* *}$ & $-0.0502^{* *}$ & $-0.0970 * * *$ \\
\hline & $(0.039)$ & $(0.063)$ & $(0.024)$ & $(0.020)$ & $(0.033)$ & $(0.026)$ & $(0.074)$ & $(0.020)$ & $(0.020)$ & $(0.027)$ \\
\hline \multirow[t]{2}{*}{ Male CEO } & -0.0908 & 1.0099 & -0.3418 & -0.1349 & -0.2027 & 0.2774 & -0.9977 & -0.2366 & -0.2048 & 0.0096 \\
\hline & $(0.424)$ & $(1.505)$ & $(0.289)$ & $(0.163)$ & $(0.301)$ & $(0.413)$ & $(1.462)$ & $(0.170)$ & $(0.170)$ & $(0.379)$ \\
\hline \multirow[t]{2}{*}{ CEO age } & 0.0008 & 0.0062 & -0.0068 & -0.0041 & 0.0015 & -0.0050 & 0.0068 & -0.0016 & -0.0012 & -0.0028 \\
\hline & $(0.010)$ & $(0.017)$ & $(0.006)$ & $(0.005)$ & $(0.008)$ & $(0.008)$ & $(0.018)$ & $(0.005)$ & $(0.005)$ & $(0.008)$ \\
\hline \multirow[t]{2}{*}{ Log(Capital intensity) } & $0.3708^{* * *}$ & $0.7103^{* * *}$ & 0.0838 & $-0.6858^{* * *}$ & -0.1247 & $0.5108^{* * *}$ & $-0.5459 * * *$ & $0.3253 * * *$ & $0.2974 * * *$ & $0.2999 * * *$ \\
\hline & $(0.095)$ & $(0.183)$ & $(0.061)$ & $(0.057)$ & $(0.082)$ & $(0.099)$ & (0.191) & $(0.056)$ & $(0.060)$ & $(0.087)$ \\
\hline \multirow[t]{2}{*}{ Asset growth } & -0.0219 & -0.1098 & $-0.2384 * * *$ & $-0.0568^{* *}$ & $-0.3287^{*}$ & 0.0158 & 0.1687 & $-0.0521 * *$ & $-0.0548^{* *}$ & 0.0309 \\
\hline & $(0.047)$ & $(0.127)$ & $(0.062)$ & $(0.028)$ & $(0.179)$ & $(0.075)$ & $(0.142)$ & $(0.025)$ & $(0.023)$ & $(0.099)$ \\
\hline \multirow[t]{2}{*}{ Total assets } & -0.0015 & 0.0088 & $-0.0124 * * *$ & $-0.0123^{* * *}$ & $-0.0180^{* * *}$ & $-0.0881 * * *$ & 0.0118 & $-0.0113^{* * *}$ & $-0.0113^{* * *}$ & $-0.1676^{* * *}$ \\
\hline & $(0.003)$ & $(0.008)$ & $(0.003)$ & $(0.003)$ & $(0.004)$ & $(0.028)$ & $(0.020)$ & $(0.002)$ & $(0.002)$ & $(0.044)$ \\
\hline Industry dummies & Yes & Yes & Yes & Yes & Yes & Yes & Yes & Yes & Yes & Yes \\
\hline Year dummies & Yes & Yes & Yes & Yes & Yes & Yes & Yes & Yes & Yes & Yes \\
\hline Observations & 2,737 & 1,527 & 2,474 & 2,556 & 1,942 & 1,332 & 1,508 & 2,491 & 2,491 & 1,080 \\
\hline Adjusted $\mathrm{R}^{2}$ & 0.26 & 0.164 & 0.129 & 0.388 & 0.141 & 0.281 & 0.634 & 0.26 & 0.293 & 0.228 \\
\hline
\end{tabular}




\section{Table 11. Fields of study}

The dependent variable is the natural logarithm of electricity consumption over number of employees. Technical advanced degree is a dummy for undergraduate or higher education in engineering or natural sciences. Business advanced degree is a dummy for undergraduate or higher education in management or economics. Other advanced degree is all undergraduate or higher educations in fields outside either technical or business. The baseline educational category is formed by all noncollege educational attainments. Male CEO is a dummy equal to one for male CEOs and zero for female CEOs. CEO age measures the years of CEO age. $\log$ (Capital intensity) is the natural logarithm of the ratio of a firm's fixed assets over its number of employees. Asset growth is the growth rate in the firm's total assets Employees are the number of employees in the firm. Total assets is the logarithm of a firm's total assets. Furthermore, our regressions include 3-digit industry and year dummies. Clustered (firm) standard errors are shown in the parenthesis. ${ }^{* * *} \mathrm{p}<0.01,{ }^{* *} \mathrm{p}<0.05, * \mathrm{p}<0.1$.

\begin{tabular}{|c|c|c|c|c|}
\hline \multicolumn{4}{|c|}{ Dependent variable: $\log (\mathrm{kWh} /$ Employees $)$} & \\
\hline & (1) & (2) & (3) & (4) \\
\hline Business advanced degree & $\begin{array}{c}-0.4578^{* * * *} \\
(0.161)\end{array}$ & $\begin{array}{c}-0.4694 * * * \\
(0.165)\end{array}$ & $\begin{array}{c}-0.5163^{* * * *} \\
(0.164)\end{array}$ & $\begin{array}{c}-0.5020^{* * *} \\
(0.163)\end{array}$ \\
\hline Technical advanced degree & $\begin{array}{c}-0.1433 \\
(0.143)\end{array}$ & $\begin{array}{c}-0.1470 \\
(0.143)\end{array}$ & $\begin{array}{l}-0.1890 \\
(0.140)\end{array}$ & $\begin{array}{c}-0.0988 \\
(0.135)\end{array}$ \\
\hline Other advanced degree & $\begin{array}{l}-0.1272 \\
(0.205)\end{array}$ & $\begin{array}{c}-0.1322 \\
(0.205)\end{array}$ & $\begin{array}{l}-0.2413 \\
(0.190)\end{array}$ & $\begin{array}{c}-0.2309 \\
(0.184)\end{array}$ \\
\hline Male CEO & & $\begin{array}{l}0.1436 \\
(0.204)\end{array}$ & $\begin{array}{c}-0.0568 \\
(0.173)\end{array}$ & $\begin{array}{c}-0.0905 \\
(0.167)\end{array}$ \\
\hline CEO age & & $\begin{array}{c}-0.0033 \\
(0.006)\end{array}$ & $\begin{array}{c}-0.0054 \\
(0.006)\end{array}$ & $\begin{array}{c}-0.0042 \\
(0.006)\end{array}$ \\
\hline Log(Capital intensity) & & & $\begin{array}{c}0.2772^{* * *} \\
(0.057)\end{array}$ & $\begin{array}{c}0.3336^{* * *} \\
(0.058)\end{array}$ \\
\hline Asset growth & & & $\begin{array}{c}-0.0611 * * \\
(0.030)\end{array}$ & $\begin{array}{c}-0.0521 * \\
(0.029)\end{array}$ \\
\hline Total assets & & & & $\begin{array}{c}-0.0133^{* * *} \\
(0.002) \\
\end{array}$ \\
\hline Industry dummies & & Yes & Yes & Yes \\
\hline Year dummies & Yes & Yes & Yes & Yes \\
\hline Observations & 2,491 & 2,491 & 2,491 & 2,491 \\
\hline Adjusted $\mathrm{R}^{2}$ & 0.108 & 0.109 & 0.158 & 0.189 \\
\hline
\end{tabular}




\section{Table 12. Relationship between CEO education and environmental concerns}

Panel A of Table 3 presents the results from an ordered logit model in which the dependent variable is the CEO's response to the survey question "Following the current trend, are we then going to experience a climate catastrophe in the near future?" Possible responses are: 1=Agree a lot; 2=Agree; 3=Neither nor; 4=Disagree, 5=Disagree a lot. Greater values correspond to weaker environmental concerns. The main explanatory variable is a CEO's years of education, CEO age, a dummy for male CEOs, and the logarithm of CEO income. Religious upbringing is measured using answers to the survey question "My childhood home was religious and religion was a big part of my adolescence" possible answers: $1=$ Disagree a lot, 2=Disagree, $3=$ Neither nor, 4=Agree, 5=Agree a lot. Family's political view is measured using answers to the survey question "How would you characterize the political view in your childhood home on a scale from one to ten, where one is left wing and 10 is right wing. Panel B presents results from a 2-stage least square model. In the first stage regression, reported in the left panel of the table, the dependent variable is CEO education and the key explanatory variables are the controls included in Panel A, together with the two instrumental variables: the education of a CEO's mother and father. The right panel of Panel B presents the second stage regression, in which the key explanatory variable is the instrumented value of CEO education from the first stage together with the controls of our baseline specification. Robust standard errors are shown in the parenthesis. ${ }^{* * *} \mathrm{p}<0.01,{ }^{* *} \mathrm{p}<0.05,{ }^{*} \mathrm{p}<0.1$

\section{Panel A. Ordered logit}

Dependent variable: Climate concern

Years of education

\begin{tabular}{cccc}
$(1)$ & $(2)$ & $(3)$ & $(4)$ \\
\hline$-0.0217^{*}$ & $-0.0217^{*}$ & $-0.0220^{*}$ & $-0.0294^{* *}$ \\
$(0.012)$ & $(0.012)$ & $(0.012)$ & $(0.012)$ \\
& $0.0101^{* * *}$ & $0.0100^{* * *}$ & $0.0083^{* *}$ \\
& $(0.004)$ & $(0.004)$ & $(0.004)$ \\
& $0.1179 *$ & 0.1135 & $0.1321^{*}$ \\
& $(0.069)$ & $(0.069)$ & $(0.069)$ \\
& 0,0009 & 0.0018 & -0.0013 \\
& $(0.031)$ & $(0.031)$ & $(0.030)$ \\
& & 0.0257 & \\
& & $(0.024)$ & \\
& & & $0.1051^{* * *}$ \\
& & & $(0.012)$ \\
\hline 5.473 & 5.473 & 5,463 & 5,439 \\
\hline
\end{tabular}

Observations

CEO age

Male CEO

$0.1179 *$

0.1135

$0.1321 *$

$\log (\mathrm{CEO}$ income $)$

0,0009

0.0018

Religious upbringing

Family's political view 
Panel B. 2SLS analysis

First stage. Dependent variable: Years of education

\begin{tabular}{|c|c|c|c|}
\hline \multirow[b]{2}{*}{ CEO age } & & & \\
\hline & $\begin{array}{c}0.0219 * * * \\
(0.004)\end{array}$ & $\begin{array}{c}0.0207 * * * \\
(0.004)\end{array}$ & $\begin{array}{c}0.0212^{* * *} \\
(0.004)\end{array}$ \\
\hline Male CEO & $\begin{array}{c}-0.1555^{*} \\
(0.0867)\end{array}$ & $\begin{array}{r}-0.1582^{*} \\
(0.0867)\end{array}$ & $\begin{array}{l}-0.1417 \\
(0.0872)\end{array}$ \\
\hline $\log (\mathrm{CEO}$ income $)$ & $\begin{array}{c}0.2318^{* * *} \\
(0.030)\end{array}$ & $\begin{array}{c}0.2312^{* * *} \\
(0.030)\end{array}$ & $\begin{array}{c}0.2305^{* * *} \\
(0.030)\end{array}$ \\
\hline Father's years of education & $\begin{array}{c}0.1040^{* * *} \\
(0.010)\end{array}$ & $\begin{array}{c}0.1049 * * * \\
(0.009)\end{array}$ & $\begin{array}{c}0.1029^{* * *} \\
(0.010)\end{array}$ \\
\hline Mother's years of education & $\begin{array}{c}0.1114 * * * \\
(0.010)\end{array}$ & $\begin{array}{c}0.1109^{* * *} \\
(0.010)\end{array}$ & $\begin{array}{c}0.1103^{* * *} \\
(0.010)\end{array}$ \\
\hline \multicolumn{4}{|l|}{ Religious upbringing } \\
\hline Family's political view & & & $\begin{array}{c}0.0424 * * * \\
(0.013) \\
\end{array}$ \\
\hline Observations & 5,463 & 5,463 & 5,439 \\
\hline $\mathrm{R}^{2}$ & 0.0892 & 0.092 & 0.092 \\
\hline$F$-statistics & 108.16 & 92.36 & 91.74 \\
\hline
\end{tabular}

Second stage. Dependent variable: Climate concern

Years of education

\begin{tabular}{ccc}
$(1)$ & $(2)$ & $(3)$ \\
\hline$-0.1324 * * *$ & $-0.1306^{* * *}$ & $-0.1502^{* * *}$ \\
-0.025 & $(0.025)$ & $(0.025)$ \\
$0.0063^{* * *}$ & $0.0062^{* * *}$ & $0.0053^{* *}$
\end{tabular}

CEO age

$0.0063^{* * *} \quad 0.0062^{* * *} \quad 0.0053^{* *}$

Male CEO

$\begin{array}{lll}-0.002 & (0.002) \quad(0.002) \\ 0.0615 & 0.0586 & 0.0641\end{array}$

$\begin{array}{lll}0.0615 & 0.0586 & 0.0641\end{array}$

$\log (\mathrm{CEO}$ income $)$

$\begin{array}{lll}-0.043 \quad(0.043) \quad(0.043) \\ 0.0268 & 0.0265 & 0.0302 *\end{array}$

$\begin{array}{lll}0.0268 & 0.0265 & 0.0302 *\end{array}$

$\begin{array}{lll}-0.018 \quad(0.018) \quad(0.018) & 0.0217\end{array}$

Religious upbringing

0.0217

$(0.014)$

Family's political view

$0.0671^{* * *}$

$(0.007)$

Observations

5,463

5,463

5,439 


\section{Table 13. Summary statistics on CEO cars}

This table shows the summary statistics for the CEOs employed in our analysis in Table 13. Panel A refers to the population of Danish CEOs, while Panel B refers to the CEOs covered in our survey about CEO values. Urban dummy is equal to one if the CEO residence is in one of the five largest municipalities in Denmark and zero otherwise. $\log (\mathrm{Km} / \mathrm{Liter}$ gas $)$ is the logarithm of a CEO car's energy efficiency measured as the ratio of kilometers per liter of gasoline. Electric car is a dummy equal to one for electric cars and zero otherwise. A complete description of each variable is provided in Table A1.

Panel A. Population of Danish CEOs

Urban dummy

Electric car

Diesel car

\begin{tabular}{ccc} 
Observations & Mean & Std. dev. \\
\hline 74,858 & 0.20 & 0.40 \\
74,858 & 0.0010 & 0.03 \\
74,858 & 0.46 & 0.50 \\
74,858 & 2.80 & 0.29 \\
\hline
\end{tabular}

$\log (\mathrm{Km} /$ Liter gas $)$

Observations Mean Std. dev.

Urban dummy

$\begin{array}{lll}4,504 & 0.17 & 0.38\end{array}$

Electric car

$\begin{array}{ll}4,504 & 0.0011\end{array}$

0.03

Diesel car

4,504

0.48

0.50

$\log (\mathrm{Km} /$ Liter gas $)$

$4,504 \quad 2.78$

0.29




\section{Table 14. CEO education and car choices}

This table presents results of OLS and the second-stage of 2SLS regressions. In the 2SLS regressions, we use as instruments for CEO education the education of a CEO's father and mother measured in years. Depending on the specification, the dependent variable is $\log (\mathrm{Km} /$ Liter gas $)$, i.e. the logarithm of the ratio of kilometers per liter of gas, or Electric car, i.e. a dummy equal to one for electric cars and zero otherwise. In Columns (1)-(3) of Panel A, we use the population of Danish CEOs. In Columns (4)-(5) we use the subsample of single (unmarried) CEOs. Years of education measures a CEO's years of schooling. Male CEO is a dummy equal to one for male CEOs and zero for female CEOs. CEO age measures the years of CEO age. Urban dummy is equal to one if the CEO lives in one of the five largest municipalities and zero otherwise. $\log$ (CEO income) is the logarithm of CEO income. $\log$ (Car weight) is the logarithm of a CEO's car. Diesel car is equal to one for diesel cars and zero otherwise. In Panel B we use the CEOs covered in our value survey of 2009. These regressions include as further controls also religious upbringing measured using answers to the survey question "My childhood home was religious and religion was a big part of my adolescence" possible answers: $1=$ Disagree a lot, $2=$ Disagree, $3=$ Neither nor, 4=Agree, $5=$ Agree a lot, and family's political view measured using answers to the survey question "How would you characterize the political view in your childhood home on a scale from one to ten, where one is left wing and 10 is right wing. Robust standard errors are shown in the parenthesis. ${ }^{* * *} \mathrm{p}<0.01,{ }^{* *} \mathrm{p}<0.05,{ }^{*} \mathrm{p}<0.1$

\begin{tabular}{|c|c|c|c|c|c|}
\hline Panel A. & & All CEO & & Singl & CEOs \\
\hline \multirow[t]{3}{*}{ Dependent variable: } & $\begin{array}{l}\log (\mathrm{Km} / \\
\text { Liter gas })\end{array}$ & $\begin{array}{l}\log (\mathrm{Km} / \\
\text { Liter gas })\end{array}$ & $\begin{array}{c}\text { Electric } \\
\text { Car }\end{array}$ & $\begin{array}{l}\mathrm{Log}(\mathrm{Km} / \\
\text { Liter gas })\end{array}$ & $\begin{array}{c}\log (\mathrm{Km} / \\
\text { Liter gas) }\end{array}$ \\
\hline & OLS & 2SLS & 2 SLS & OLS & 2SLS \\
\hline & $(1)$ & $(2)$ & (3) & (4) & $(5)$ \\
\hline Years of education & $\begin{array}{c}0.0043^{* * *} \\
(0.000)\end{array}$ & $\begin{array}{c}0.0080^{* * *} \\
(0.001)\end{array}$ & $\begin{array}{c}0.0005^{* *} \\
(0.000)\end{array}$ & $\begin{array}{c}0.0044^{* * *} \\
(0.001)\end{array}$ & $\begin{array}{l}0.0052 \\
(0.006)\end{array}$ \\
\hline $\mathrm{Log}(\mathrm{CEO}$ income $)$ & $\begin{array}{c}0.0086^{* * *} \\
(0.001)\end{array}$ & $\begin{array}{c}0.0075^{* * *} \\
(0.001)\end{array}$ & $\begin{array}{l}0.0000 \\
(0.000)\end{array}$ & $\begin{array}{l}0.0037 \\
(0.003)\end{array}$ & $\begin{array}{l}0.0035 \\
(0.003)\end{array}$ \\
\hline Male CEO & $\begin{array}{c}-0.0074 * * * \\
(0.002)\end{array}$ & $\begin{array}{c}-0.0066^{* * *} \\
(0.002)\end{array}$ & $\begin{array}{l}0.0003 \\
(0.000)\end{array}$ & $\begin{array}{c}-0.0513^{* * *} \\
(0.007)\end{array}$ & $\begin{array}{c}-0.0511^{* * *} \\
(0.007)\end{array}$ \\
\hline CEO age & $\begin{array}{c}-0.0002^{* *} \\
(0.000)\end{array}$ & $\begin{array}{c}-0.0002^{* *} \\
(0.000)\end{array}$ & $\begin{array}{r}-0.0000 \\
(0.000)\end{array}$ & $\begin{array}{c}-0.0003 \\
(0.000)\end{array}$ & $\begin{array}{c}-0.0003 \\
(0.000)\end{array}$ \\
\hline Urban dummy & $\begin{array}{c}-0.0088^{* * *} \\
(0.002)\end{array}$ & $\begin{array}{c}-0.0111^{* * *} \\
(0.002)\end{array}$ & $\begin{array}{c}-0.0003 \\
(0.000)\end{array}$ & $\begin{array}{l}0.0006 \\
(0.006)\end{array}$ & $\begin{array}{l}0.0000 \\
(0.007)\end{array}$ \\
\hline $\log ($ Car weight $)$ & $\begin{array}{c}-0.9565^{* * *} \\
(0.007)\end{array}$ & $\begin{array}{c}-0.9576^{* * *} \\
(0.008)\end{array}$ & $\begin{array}{c}0.0037 * * * \\
(0.001)\end{array}$ & $\begin{array}{c}-1.0809 * * * \\
(0.022)\end{array}$ & $\begin{array}{c}-1.0804^{* * *} \\
(0.022)\end{array}$ \\
\hline Diesel car & $\begin{array}{c}0.4023^{* * *} \\
(0.002) \\
\end{array}$ & $\begin{array}{c}0.4026^{* * *} \\
(0.002) \\
\end{array}$ & & $\begin{array}{c}0.4446^{* * *} \\
(0.006) \\
\end{array}$ & $\begin{array}{c}0.4445^{* * *} \\
(0.006) \\
\end{array}$ \\
\hline Adjusted $\mathrm{R}^{2}$ & 0.550 & 0.549 & & 0.650 & 0.650 \\
\hline Observations & 74,858 & 74,858 & 74,858 & 4,180 & 4,180 \\
\hline
\end{tabular}




\begin{tabular}{|c|c|c|c|c|c|c|}
\hline \multirow{2}{*}{$\begin{array}{l}\text { Panel B. } \\
\text { Dependent variable: }\end{array}$} & \multicolumn{6}{|c|}{ CEOs covered in the survey } \\
\hline & $\begin{array}{l}\log (\mathrm{Km} / \\
\text { Liter gas })\end{array}$ & $\begin{array}{l}\log (\mathrm{Km} / \\
\text { Liter gas })\end{array}$ & $\begin{array}{l}\log (\mathrm{Km} / \\
\text { Liter gas }) \\
\end{array}$ & $\begin{array}{l}\log (\mathrm{Km} / \\
\text { Liter gas })\end{array}$ & $\begin{array}{l}\log (\mathrm{Km} / \\
\text { Liter gas }) \\
\end{array}$ & $\begin{array}{l}\mathrm{Log}(\mathrm{Km} / \\
\text { Liter gas }) \\
\end{array}$ \\
\hline & OLS & OLS & OLS & 2SLS & 2SLS & 2SLS \\
\hline & (1) & (2) & (3) & (4) & (5) & (6) \\
\hline Years of education & $\begin{array}{c}0.0035^{* *} \\
(0.001)\end{array}$ & $\begin{array}{c}0.0036^{* *} \\
(0.001)\end{array}$ & $\begin{array}{c}0.0034^{* *} \\
(0.001)\end{array}$ & $\begin{array}{c}0.0104^{* *} \\
(0.005)\end{array}$ & $\begin{array}{c}0.0104 * * \\
(0.005)\end{array}$ & $\begin{array}{c}0.0103^{* *} \\
(0.001)\end{array}$ \\
\hline $\log (\mathrm{CEO}$ income $)$ & $\begin{array}{c}0.0104^{* * *} \\
(0.003)\end{array}$ & $\begin{array}{c}0.0104 * * * \\
(0.003)\end{array}$ & $\begin{array}{c}0.0106^{* * *} \\
(0.003)\end{array}$ & $\begin{array}{c}0.0086^{* *} \\
(0.004)\end{array}$ & $\begin{array}{c}0.0086^{* *} \\
(0.004)\end{array}$ & $\begin{array}{c}0.0087^{* *} \\
(0.004)\end{array}$ \\
\hline Male CEO & $\begin{array}{c}-0.0075 \\
(0.009)\end{array}$ & $\begin{array}{c}-0.0074 \\
(0.009)\end{array}$ & $\begin{array}{c}-0.0066 \\
(0.009)\end{array}$ & $\begin{array}{c}-0.0068 \\
(0.009)\end{array}$ & $\begin{array}{c}-0.0068 \\
(0.009)\end{array}$ & $\begin{array}{c}-0.0058 \\
(0.009)\end{array}$ \\
\hline CEO age & $\begin{array}{c}-0.0010^{* *} \\
(0.000)\end{array}$ & $\begin{array}{c}-0.0010^{* *} \\
(0.000)\end{array}$ & $\begin{array}{c}-0.0010^{* *} \\
(0.000)\end{array}$ & $\begin{array}{c}-0.0010^{* *} \\
(0.000)\end{array}$ & $\begin{array}{c}-0.0010^{* *} \\
(0.000)\end{array}$ & $\begin{array}{c}-0.0010^{* *} \\
(0.000)\end{array}$ \\
\hline Urban dummy & $\begin{array}{c}-0.0028 \\
(0.008)\end{array}$ & $\begin{array}{c}-0.0031 \\
(0.008)\end{array}$ & $\begin{array}{c}-0.0025 \\
(0.008)\end{array}$ & $\begin{array}{c}-0.0072 \\
(0.008)\end{array}$ & $\begin{array}{c}-0.0074 \\
(0.008)\end{array}$ & $\begin{array}{c}-0.0072 \\
(0.008)\end{array}$ \\
\hline Log(Car weight $)$ & $\begin{array}{c}-0.9777^{* * *} \\
(0.021)\end{array}$ & $\begin{array}{c}-0.9774 * * * \\
(0.021)\end{array}$ & $\begin{array}{c}-0.9768^{* * *} \\
(0.021)\end{array}$ & $\begin{array}{c}-0.9787^{* * *} \\
(0.021)\end{array}$ & $\begin{array}{c}-0.9783^{* * *} \\
(0.021)\end{array}$ & $\begin{array}{c}-0.9778^{* * *} \\
(0.021)\end{array}$ \\
\hline Diesel car & $\begin{array}{c}0.3984 * * * \\
(0.007)\end{array}$ & $\begin{array}{c}0.3982^{* * *} \\
(0.007)\end{array}$ & $\begin{array}{c}0.3982^{* * *} \\
(0.007)\end{array}$ & $\begin{array}{c}0.3989 * * * \\
(0.007)\end{array}$ & $\begin{array}{c}0.3987 * * * \\
(0.007)\end{array}$ & $\begin{array}{c}0.3985^{* * *} \\
(0.007)\end{array}$ \\
\hline Religious upbringing & & $\begin{array}{c}0.0002 \\
(0.0003)\end{array}$ & & & $\begin{array}{l}-0.0005 \\
(0.0003)\end{array}$ & \\
\hline Family's political view & & & $\begin{array}{l}0.0006 \\
(0.001)\end{array}$ & & & $\begin{array}{c}0.0003 \\
(0.0001)\end{array}$ \\
\hline Adjusted R ${ }^{2}$ & $\begin{array}{l}0.533 \\
4.504\end{array}$ & $\begin{array}{l}0.532 \\
4.497\end{array}$ & $\begin{array}{l}0.532 \\
4777\end{array}$ & $\begin{array}{l}0.530 \\
4504\end{array}$ & $\begin{array}{l}0.530 \\
4.497\end{array}$ & $\begin{array}{l}0.529 \\
4777\end{array}$ \\
\hline
\end{tabular}




\section{Figure A1. The Danish educational system}

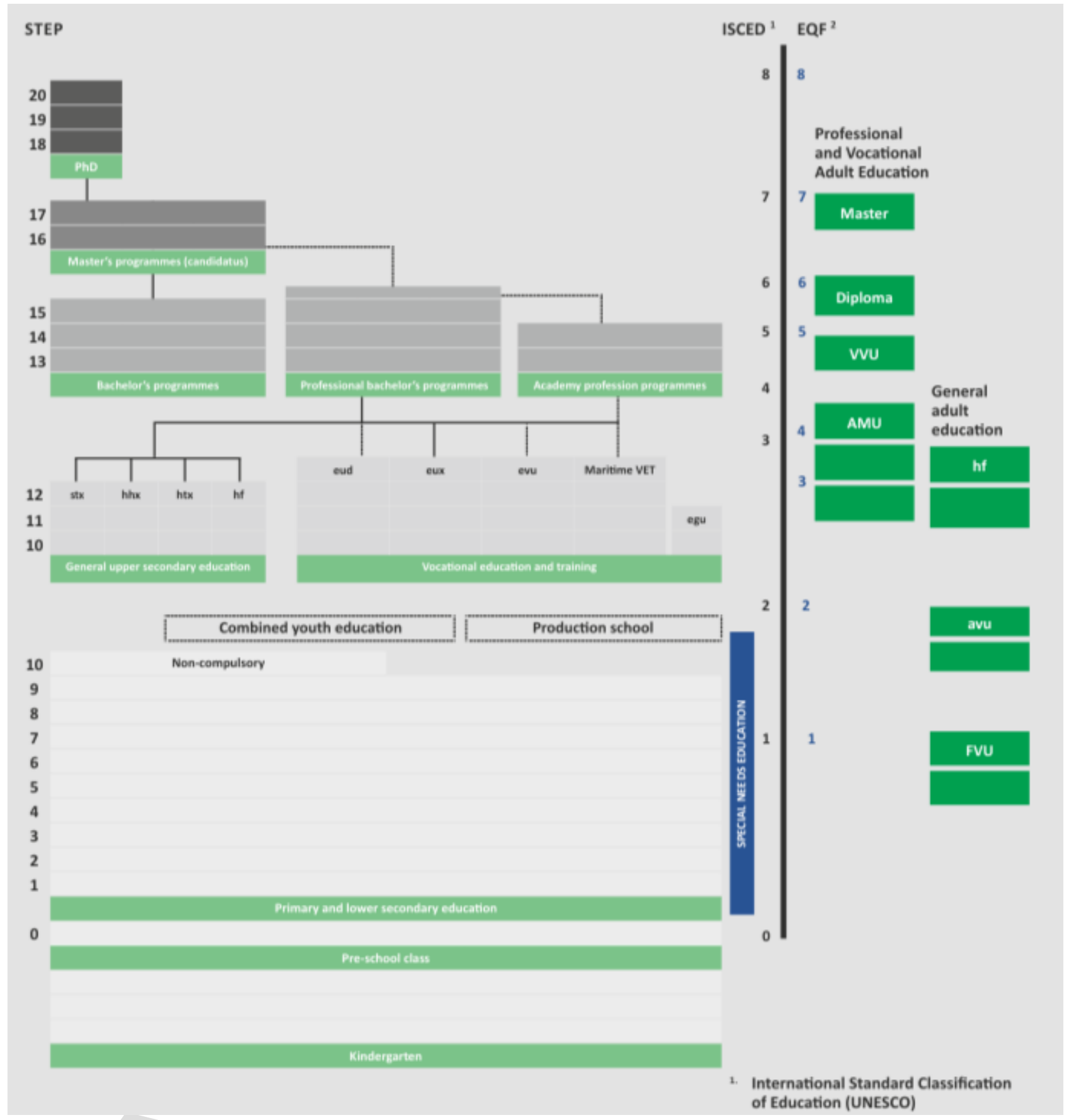




\section{Table A1. List of variables}

\begin{tabular}{|c|c|}
\hline Name & Description \\
\hline \multicolumn{2}{|l|}{ Financial variables } \\
\hline Total assets & The value of the firm's total assets \\
\hline Gross profits & Yearly gross profit \\
\hline Capital intensity & The ratio of capital (total assets) to labor (employees) \\
\hline Asset growth & The percentage yearly change in total assets \\
\hline Employees & The total number of the firm's employees \\
\hline Fixed assets & Tangible assets such as property, plant, equipment etc. \\
\hline Pretax earnings & Earnings after operating expenses and before tax \\
\hline \multicolumn{2}{|l|}{ CEO characteristics } \\
\hline CEO age & The age of the CEO \\
\hline CEO male & Dummy $=1$ if the CEO is a male \\
\hline Years of education & The duration of the CEO's highest educational degree in years \\
\hline Non college degree & $\begin{array}{l}\text { Consists of lower and upper secondary, vocational, and short academy } \\
\text { professional programs }\end{array}$ \\
\hline Undergraduate degree & $\begin{array}{l}\text { Consists of 3-3.54 years long post high school professional bachelor and } \\
\text { undergraduate programs }\end{array}$ \\
\hline Master or PhD degree & Consists of university graduate programs \\
\hline Short education & $\begin{array}{l}\text { Dummy }=1 \text { if the CEO's highest education is shorter than a college } \\
\text { degree }\end{array}$ \\
\hline Long technical education & $\begin{array}{l}\text { Dummy }=1 \text { if the CEO's has a master or PhD degree in engineering or } \\
\text { natural sciences }\end{array}$ \\
\hline Long business educations & $\begin{array}{l}\text { Dummy }=1 \text { if the CEO's has a master or PhD degree in business or } \\
\text { economics }\end{array}$ \\
\hline Long other education & $\begin{array}{l}\text { Dummy }=1 \text { if the CEO's has a master or PhD degree in any other field } \\
\text { than in a business or technical field }\end{array}$ \\
\hline $\log (\mathrm{CEO}$ income $)$ & $\begin{array}{l}\text { The CEO's yearly cash payments, excluding benefits, stock option or } \\
\text { other non-cash payments }\end{array}$ \\
\hline CEO ownership & Dummy $=1$ if the CEO own more than 5 per cent of the firm \\
\hline Urban dummy & $\begin{array}{l}\text { Dummy }=1 \text { if the CEO lives in one of the five most populated } \\
\text { municipalities in Denmark }\end{array}$ \\
\hline Fathers' years of education & Years of education obtained by the father of the CEO \\
\hline Mothers' years of education & Years of education obtained by the mother of the CEO \\
\hline Days at hospitalization $[t, t-1]$ & $\begin{array}{l}\text { Days during which the CEOs has been hospitalized in the year up to and } \\
\text { in the current year }\end{array}$ \\
\hline \multicolumn{2}{|l|}{ Firm’s energy efficiency } \\
\hline Electricity & Yearly electricity consumption measured in $1,000 \mathrm{kWh}$ \\
\hline $\log (\mathrm{kWh} /$ Employees $)$ & The logarithm of the firm's electricity consumption over its employees \\
\hline $\log (\mathrm{kWh} /$ Gross profits $)$ & The logarithm of the firm's electricity consumption over its gross profits \\
\hline $\log (\mathrm{kWh} /$ Pre-tax earnings $)$ & $\begin{array}{l}\text { The logarithm of the firm's electricity consumption over its pre-tax } \\
\text { earnings }\end{array}$ \\
\hline $\log (\mathrm{kWh} /$ Fixed assets $)$ & The logarithm of the firm's electricity consumption over its fixed assets \\
\hline Water, $\mathrm{M}^{3}$ & Yearly water consumption measured in 1,000 cubic meters \\
\hline
\end{tabular}


$\log ($ Water/Gross profits)

Gas $\mathrm{M}^{3}$

$\log$ (Gas/Gross profits)

BTU
The logarithm of the firm's water consumption over its gross profits Yearly gas consumption measured in 1,000 cubic meters

The logarithm of the firm's gas consumption over its gross profits

British Thermal Unit

Environmental variables at the CEO level

Survey question: Following the current trend, are we then going to

Climate concern experience a climate catastrophe in the near future?

Categories: 1. Agree a lot, 2. Agree, 3. Neither nor, 4. Disagree, 5. Disagree a lot

Religious upbringing Survey question: CEOs' perception of how religious his/her upbringing was on a scale from 1 to 5 (1: not religious - 5: very religious)

Survey question: CEOs' perception of his family's political view in

Family's political view his/her upbringing on a scale from 1 to 10 (1: Left wing - 10. Right wing)

$\log (\mathrm{Km} /$ Liter gas $)$

The logarithm of the most fuel-efficient car at the CEO's household,

$\log ($ car weight $)$ measured by distance (in kilometers) the car runs per liter gas (number provided by producer)

Diesel car The logarithm of the weight of the heaviest car in the CEO's household

Electric car Dummy $=1$ if the CEO's household owns a diesel car Dummy $=1$ if the CEO's household owns an electric car 